\title{
The Effects of Climate Seasonality on Behavior and Sleeping Site Choice in Sahamalaza Sportive Lemurs, Lepilemur sahamalaza
}

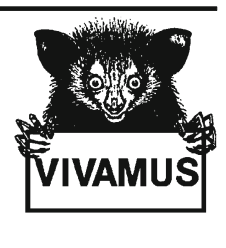

\author{
Isabella Mandl ${ }^{1}$ (D) Marc Holderied ${ }^{1} \cdot$ Christoph Schwitzer $^{2}$
}

Received: 1 February 2018 / Accepted: 22 June 2018 / Published online: 11 September 2018

(C) The Author(s) 2018

\begin{abstract}
Temperature, rainfall, and resource availability may vary greatly within a single year in primate habitats. Many primate species show behavioral and physiological adaptations to this environmental seasonality, including changes to their diets and activity. Sahamalaza sportive lemurs (Lepilemur sahamalaza) inhabit the northwest of Madagascar and have been studied only during the dry, colder period of the year. We investigated potential effects of climate seasonality on this species by collecting behavioral data between October 2015 and August 2016, encompassing both the warmer wet and the colder dry seasons. We collected 773.15 hours of behavioral data on 14 individual sportive lemurs to investigate year-round activity budgets, ranging behavior, and sleeping site locations. Additionally we recorded temperature and rainfall data at our study site to describe the environmental conditions during the study period. The study individuals significantly decreased their time spent traveling and increased their time spent resting in the dry season compared to the wet season. Although home range size and path lengths did not differ over the study period, sleeping locations were significantly different between seasons as the lemurs focused on more confined areas in colder periods. Overall, the results indicate that Sahamalaza sportive lemur behavior varies with season, in line with reports for other primates.
\end{abstract}

Keywords Adaptation · Behavior · Nocturnal · Seasonal · Strepsirrhines

Handling Editor: Joanna M. Setchell

Electronic supplementary material The online version of this article (https://doi.org/10.1007/s10764-0180059-1) contains supplementary material, which is available to authorized users.

Isabella Mandl

i.mandl@gmx.at

1 School of Biological Sciences, University of Bristol, Bristol BS8 1TQ, UK

2 Bristol Zoological Society, Bristol Zoo Gardens, Clifton, Bristol BS8 3HA, UK 


\section{Introduction}

Most primate species inhabit tropical and subtropical regions (Myers et al. 2000; Wilson 1988). These regions are characterized by high precipitation and, to varying extent, seasonality. Seasonality is commonly defined as "the occurrence of certain obvious biotic and abiotic events, or groups of events, within a definite limited period, or periods, of the astronomic (solar or calendar) year" (Lieth 1974, p. 5). The degree of seasonality depends on latitude, as habitats closer to the equator do not show pronounced fluctuations in abiotic factors, such as rainfall and temperature (Addo-Bediako et al. 2000; Stevens 1989; van Schaik and Pfannes 2005). In these regions, rainfall occurs year-round or in multiple shorter rainy seasons. These short periods merge into one longer rainy season as one moves away from the equator (van Schaik and Pfannes 2005). Dry seasons, which are usually defined as the number of subsequent months in which rainfall is $<100 \mathrm{~mm} / \mathrm{mo}$ (Hemingway and Bynum 2005; van Schaik and Pfannes 2005), therefore increase in length with increasing latitude, resulting in more pronounced seasonal differences in climate (van Schaik and Pfannes 2005). Similarly, year-round fluctuations in photoperiod increase with increasing latitude (Hill 2005).

Recurring oscillations in rainfall, temperature, and photoperiod may affect biotic factors such as plant phenology (Lieth 1974). The resulting variation in food and water availability may influence and shape aspects of primate ecology and behavior by affecting year-round activity budgets, diet composition, and habitat use (Brockman and van Schaik 2005). Seasonality can further influence the timing of physiological processes such as reproduction (Brockman and van Schaik 2005; Rasmussen 1985) and can affect primates indirectly via varying levels of predation pressure throughout the year (Gursky and Nekaris 2007; Irwin et al. 2009; Karpanty and Wright 2007; Mitani and Watts 2005; Rasmussen 2005).

Correlations among temperature fluctuations, changes in day length, and food-rich (or scarce) periods make it difficult to identify a single underlying mechanism driving primate behavioral adaptations (Brockman and van Schaik 2005) and limit our ability to predict the effects of climate change on primates. Generally, in times of low resource abundance, primates switch diets, increase their ranging, or attempt to save energy by reducing their overall activity (Ganzhorn et al. 2003). However, resource abundance can be coupled with abiotic variables such as temperature and rainfall (Tutin and Fernandez 1993; van Schaik et al. 1993), which themselves can affect primate behavior (Brockman and van Schaik 2005). Therefore, it is likely that primate ecology and behavior is shaped by an interplay of all these factors, as suggested for lemurs (Wright 1999). Madagascar lies in the most southern tropical latitudes and is characterized by varying degrees of seasonality (Richard et al. 2002; Wright 1999; van Schaik and Pfannes 2005): the central highlands as well as the western and northern regions are marked by long dry seasons, while the southern region is characterized by very little overall rainfall; high precipitation is common throughout the year in the eastern region of the island (Ganzhorn et al. 2001; Tattersall and Sussman 1975).

Across Madagascar, lemurs have evolved multiple adaptations to conserve energy in environmentally stressful times (such as cold, dry seasons): most species show low basal metabolic rates and highly seasonal reproduction while torpor and hibernation are common among the smaller lemuroids (Kappeler and Ganzhorn 1993; Wright 1999). Thermoregulatory and energy-conserving behavior often occurs in areas with a 
prolonged dry season - a period in Madagascar marked by lower temperatures, little precipitation, and food and water scarcity (Sato et al. 2014; Wright 1999). Diurnal and cathemeral lemur species rest more, travel less, and increase sunbathing behavior during the dry season, particularly when ambient temperatures are low, e.g., in collared brown lemurs (Eulemur collaris: Campera et al. 2014; Donati et al. 2010), diademed sifakas (Propithecus diadema: Irwin 2014), brown lemurs (E. fulvus rufus: Sato 2012), ring-tailed lemurs (Lemur catta: Simmen et al. 2010), and ruffed lemurs (Varecia rubra: Vasey 2005; V. variegata variegata: Morland 1993). Decreased activity levels are not the only strategy lemurs use: brown lemurs (E. fulvus rufus) inhabiting the highly seasonal northwest of Madagascar show a combination of dietary and habitat changes in response to fruit scarcity during the dry season (Sato 2013; Sato et al. 2014).

For small-bodied, nocturnal lemurs, seasonality in climate may impose even greater constraints as temperatures during the dry season drop significantly at night (Aujard et al. 1998). To cope with this environment, members of the family Cheirogaleidae often hibernate during cooler periods of the year (Blanco and Rahalinarivo 2010; Dausmann et al. 2004; Fietz and Dausmann 2006; Kobbe et al. 2014; Ortmann et al. 1997; Schmid 2000; Schülke and Ostner 2007). Nocturnal species that do not hibernate or show seasonal torpor, however, exhibit similar behavioral adaptations to diurnal lemurs: sportive lemurs of the family Lepilemuridae rest more and travel less during the dry, colder season (Dröscher and Kappeler 2014; Dröscher et al. 2016; Ganzhorn 1993; Hladik and Charles-Dominique 1974; Nash 1998). Their reproduction is highly seasonal, and births are timed around the end of the dry season (Hilgartner 2006). These small (600-1200 g; Mittermeier et al. 2010), arboreal primates are highly folivorous (Dröscher and Kappeler 2014; Hladik and Charles-Dominique 1974; Hladik et al. 1980; Seiler et al. 2014). Recent studies show that, although many sportive lemur species occur in deciduous forests where leaf availability fluctuates, dry seasons may not necessarily pose energy constraints in terms of food scarcity, but rather induce cold stress (Dröscher et al. 2016; Dröscher and Kappeler 2014; Ganzhorn 2002). As a behavioral response, sportive lemurs decrease their activity levels and ranging distance and increase resting times during the colder period (Ganzhorn et al. 2004; Nash 1998). White-footed sportive lemurs (Lepilemur leucopus) even increase food intake and time spent feeding during the colder period, possibly to compensate for higher energetic demands due to colder temperatures (Dröscher and Kappeler 2014; Dröscher et al. 2016).

As most sportive lemur species were described only in the past decade (Andriaholinirina et al. 2006; Craul et al. 2007), we have limited knowledge of their behavior and ecology in comparison to what is available for other primate taxa. This includes the Critically Endangered Sahamalaza sportive lemur, Lepilemur sahamalaza (the name was changed recently from L. sahamalazensis: Andriaholinirina et al. 2017), inhabiting the last remaining forests of the Sahamalaza Peninsula in northwest Madagascar. Previous studies that collected data exclusively during the colder, dry season indicate that Sahamalaza sportive lemurs are overall very inactive, with long resting bouts between short bursts of activity (Seiler et al. 2015) and that they adjust their behavior to rainfall, e.g., by switching between sleeping sites (Seiler et al. 2013). However, owing to the high seasonality in this region, with dry seasons lasting up to 6 mo each year (Volampeno et al. 2011), the results may not provide a complete understanding of Sahamalaza sportive lemur behavior. 
We conducted year-round nocturnal behavioral observations of 14 Sahamalaza sportive lemurs to record activity budgets. We hypothesized that the species' activity budget and sleeping site locations differ between the wet and dry season. If the seasonality of the habitat, measured as temperature and rainfall fluctuations throughout the year, is an environmental stressor, then we predicted that Sahamalaza sportive lemurs would show behavioral adaptations to this variable environment by adjusting activity budgets, ranging behavior, and sleeping site choice. Specifically, we predicted that Sahamalaza sportive lemurs would rest more and travel less in colder periods. We further predicted that home range size would decrease as a reflection of a decrease in general activity but did not predict that the home range location would move between the wet and the dry season. Finally, we investigated the effects of seasonality on sleeping site location, predicting a shift between months with rainfall and those without.

\section{Methods}

\section{Study Site}

We conducted the study in Ankarafa Forest in Sahamalaza-Iles Radama National Park, in northwestern Madagascar (Fig. 1). Ankarafa Forest is the most western forest patch in the protected area located between $13^{\circ} 52^{\prime} \mathrm{S}$ and $14^{\circ} 27^{\prime} \mathrm{S}$ as well as $45^{\circ} 38 \mathrm{E}$ and $14^{\circ} 46^{\prime} \mathrm{E}$ and is characterized by a mix of dry deciduous and Sambirano rainforest vegetation structures with a canopy up to $25 \mathrm{~m}$ in height, as is typical for Malagasy lowland forests (de Gouvenain and Silander 2003; Dumetz 1999; Grubb 2003; Volampeno et al. 2013). The forest consists mainly of regenerated forest with some old growth vegetation remaining (Seiler et al. 2013), and human activities and anthropogenically caused fires have influenced the vegetation structure: differently degraded patches occur throughout the forest. In addition, nearly a quarter of the forest is composed of exotic and invasive species, such as mango trees, Mangifera indica, and nonnative bamboo, Bambusa sp. (Schwitzer et al. 2007; Volampeno et al. 2013).

We collected data for 10 mo between October 2015 and August 2016 covering the wet season (October-March) and the dry season (April-September). We further divided the seasons into early and late subseasons to improve the resolution of the data (Table I). We based this division on preliminary weather data (early subseasons incorporate the transition periods) and on Sahamalaza sportive lemur reproductive patterns (birth, premating, mating, and postmating) based on previous observations and preliminary data (Ruperti 2007; Seiler et al. 2015). Infants were born between late September and early November, while F. Ruperti observed mating in May and early June. During the study period we recorded daily minimum and maximum temperatures, measured with digital thermometers (TFA Dostmann, Wertheim, Germany), and measured daily rainfall using a simple rain gauge.

\section{Study Subjects}

We captured 14 Sahamalaza sportive lemurs between September and October 2015 in the study forest and fitted them with radio-collars (3.5 g, Biotrack, Wareham, UK). 


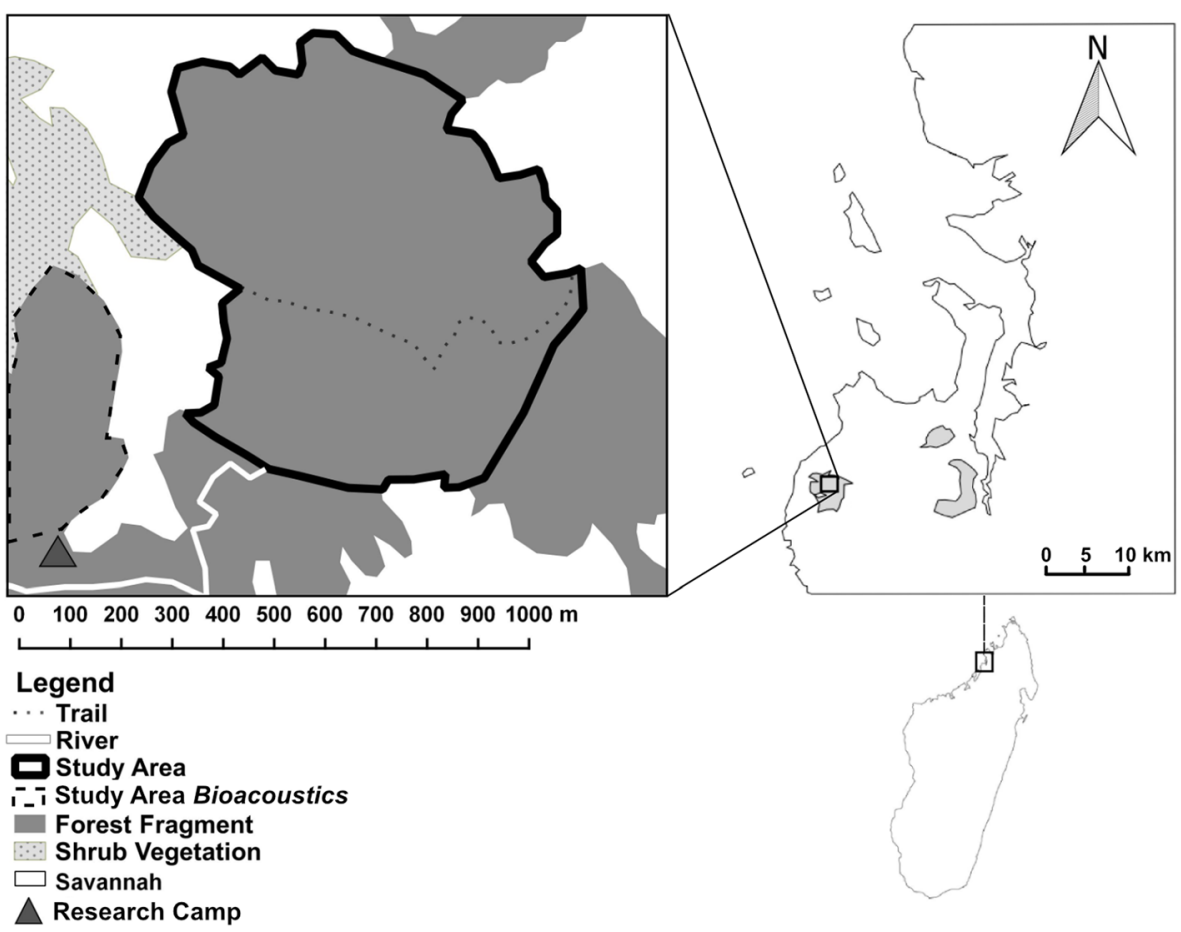

Fig. 1 Location of the study site in Ankarafa Forest, Sahamalaza National Park (gray shaded area, first insert), Sahamalaza Peninsula, northwest Madagascar. The study area (black outline, second insert) is ca. 50 ha in size. Data were collected between October 2015 and August 2016.

Four individuals vanished during the data collection period: we assumed three deaths were due to predation as we found carcasses or remains; we could not account for one disappearance. Three individuals vanished at the beginning of the early dry season and the fourth at the end of the study. Unless stated otherwise, we included data for all available individuals in the analyses.

\section{Annual Activity Budget and Home Ranges}

We conducted behavioral observations on the radio-collared individuals throughout the study. Two teams, consisting each of three observers, followed two individuals simultaneously 18:00 $\mathrm{h}-24: 00 \mathrm{~h}$; each team used a SIKA radiotracking receiver (Biotrack, Wareham, UK) and 3-element Yagi antenna (Biotrack Wareham, UK). In a pilot study, I. Mandl calculated activity budgets from $327.7 \mathrm{~h}$ of continuous behavioral observation on six individual Sahamalaza sportive lemurs between July and October 2013. Comparing the percentage of time spent on each individual behavior (see Table II) with paired $t$-tests for the first $(18: 00 \mathrm{~h}-24: 00 \mathrm{~h})$ and the second half of the night $(0: 00 \mathrm{~h}-06: 00 \mathrm{~h})$ revealed no statistically significant differences (resting: $t_{(5)}=0.97, p=0.39$; feeding: $t_{(5)}=$ $0.9, P=0.40$; grooming: $t_{(5)}=-0.7, P=0.52$; locomotion: $t_{(5)}=1.2, P=0.21$, and not visible: $\left.t_{(5)}=1.5, P=0.19\right)$. We therefore collected behavioral data only during the first half of the night. The observers followed the focal individuals using 


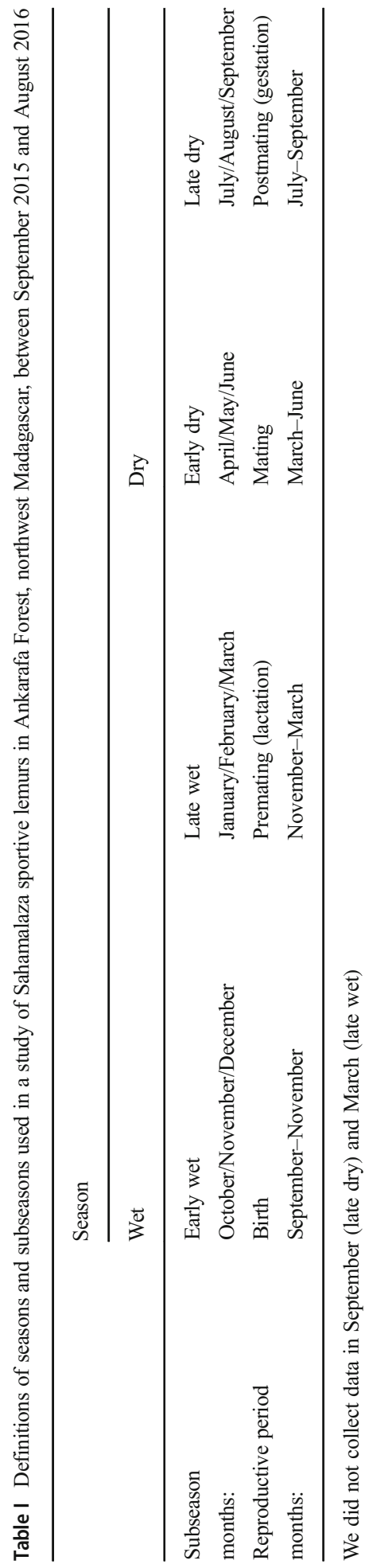


headlamps and torches and dimmed these lights if the animals were close. We recorded behaviors continuously, as described in the ethogram (Table II), giving a detailed activity budget for each individual. We recorded GPS points with a handheld GPS (GPSMAP 60CSx, Garmin Ltd., Schaffhausen, Switzerland) at each tree the focal individual visited during observation. Although observations of behaviors were often difficult because of the dense canopy, the sportive lemurs did not show flight behaviors typical of other primates and occasionally approached the observers as close as $1 \mathrm{~m}$ to settle and feed. The observers aimed to avoid disturbance to natural behaviors where possible.

\section{Sleeping Sites}

We visited the study individuals at their sleeping sites three times a week during the study (Fig. 2). We located individuals at their sleeping sites and identified them with the help of their radio-collars. We recorded a GPS point for the sleeping site with a handheld GPS if we could locate it clearly. If animals were not visible, we ascertained their location using the signals of the radio-collars and triangulation. We recorded the visibility of the individual (visible/not visible) at each site. The time of day we recorded sleeping site locations varied throughout the study period, but we assume that this did not influence our data, as Sahamalaza sportive lemurs do not usually move or change sleeping sites during the daytime (Ruperti 2007; Seiler et al. 2013). If we could not identify the sleeping tree clearly, we did not take a GPS point.

\section{Analysis}

Temperature and Rainfall We calculated the mean minimum and maximum temperatures for each month and each subseason and compared them between subseasons using a Kruskal-Wallis analysis of variance. We calculated total rainfall for each month. Rainfall occurred mainly during the daytime but we terminated five nightly

Table II Ethogram of recorded behaviors during nocturnal observations of Sahamalaza sportive lemurs in Ankarafa Forest, northwest Madagascar, between October 2015 and August 2016

Behavior Description

Resting Vigilant The lemur is stationary but alert, looking around and directing its gaze in various directions.

Resting The lemur sits on a support, is not alert, and directs its gaze in one direction, eyes half-closed or closed.

Feeding The lemur is handling food and eats, chewing visibly or audibly. If the lemur was partially or wholly out of view, we ascertained feeding behavior by the characteristic rustling and dropping of half-eaten food items, such as leaves.

Grooming The lemur is licking or scratching its fur.

Locomotion The lemur moved, by walking, climbing, or jumping, over a distance of $>50 \mathrm{~cm}$. If the lemur was partially or wholly out of view, we ascertained locomotion by movement of branches and leaves at the animals' location.

Other Behaviors not described above, including social interactions, vocalizing, and infant care.

Not visible The lemur is not clearly visible and we cannot observe its behavior. 


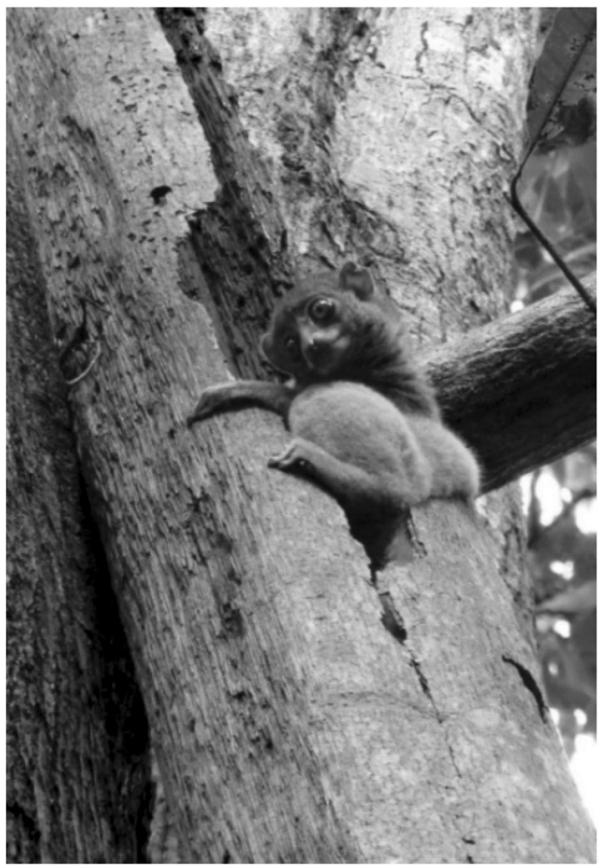

Fig. 2 A Sahamalaza sportive lemur (F3) in Ankarafa Forest, Sahamalaza National Park, northwest Madagascar resting at a sleeping site during the day in July 2016.

observations in February early because of excessive rainfall. We excluded these from our analysis. We, therefore, did not examine the effects of rainfall on behavior. We considered rainfall only in analysis of path lengths for nights where rainfall was light enough to allow for full behavioral observations.

Activity Budget, Home Range Size, and Path Length We collected 773.15 h of behavioral data between October 2015 and August 2016. We determined activity budgets using only the time the animals were clearly visible (Table III). We calculated the percentage of time an individual spent on each behavior for each subseason. To test whether season affected activity budgets we computed linear mixed models (LMMs) for each behavior, the response variables being the percentages of time engaged in the behavior, the fixed effects being subseason (early wet, late wet, early dry, late dry) and sex (male/female), and an interaction between the two. We set individual ID as a random effect to account for interindividual differences. We also controlled for differences in behavior due to similarities in habitat structure by including a random effect of forest area. We classified individuals whose home ranges overlapped to any degree as living in the same area, resulting in five forest areas). We added 0.5 to all values to eliminate analysis problems arising from 0 values and log-transformed the response variables to achieve normality.

To compute home range sizes, we visualized all GPS points collected during behavioral observations using Quantum GIS (ver. 2.14.0, QGIS Development Team). We excluded eight points, as they were clearly not within the range of the respective individuals (e.g., lying up to $1 \mathrm{~km}$ outside the forest border), indicating measurement 
Table III GPS points and total observation time for 14 radio-collared Sahamalaza sportive lemurs observed in Ankarafa Forest, northwest Madagascar between October 2015 and August 2016

\begin{tabular}{llll}
\hline Individual & $\begin{array}{l}\text { Total observation time }(\mathrm{h}) \\
\text { including time not visible }\end{array}$ & $\begin{array}{l}\text { Observation time } \\
\text { when visible }(\mathrm{h})\end{array}$ & $\begin{array}{l}\text { Number of } \\
\text { GPS points }\end{array}$ \\
\hline F1 & 62.75 & 23.34 & 398 \\
F2 $\dagger$ & 38.75 & 17.78 & 287 \\
F3 $\dagger$ & 51.75 & 31.92 & 459 \\
M4 $\dagger$ & 22.00 & 12.03 & 301 \\
F5 & 64.75 & 33.47 & 215 \\
F6 & 59.45 & 34.42 & 126 \\
F7 & 65.00 & 35.68 & 349 \\
M8 & 64.25 & 27.49 & 319 \\
F9 & 78.15 & 50.40 & 493 \\
M10 $\dagger$ & 24.50 & 13.18 & 106 \\
M11 & 63.75 & 32.89 & 428 \\
M12 & 61.75 & 37.60 & 587 \\
F13 & 60.15 & 26.40 & 407 \\
M14 & 56.15 & 24.76 & 200 \\
Total & 773.15 & 401.47 & 4675 \\
\hline
\end{tabular}

$\dagger$ Individuals that died or vanished during the study

errors. We used the remaining GPS points to compute kernel density estimation (KDE) distributions: home ranges that illustrate a percentage likelihood of an animal residing in a given area based on the GPS relocations (Worton 1989). We calculated 50 and 99\% KDEs for each individual using a least-squares cross validation (LSCV) bandwidth selector. We chose $99 \%$ KDEs rather than the commonly used $95 \%$ density estimation because LSCV may undersmooth estimations of small home ranges of $<1$ ha, giving very conservative results (Blundell et al. 2001; Seaman and Powell 1996; Steury et al. 2010). We did not follow a fixed time schedule but collected GPS points for every tree we saw the lemurs visit, resulting in varied temporal autocorrelation and different sample sizes. As the study individuals often rested in the same tree for multiple hours, a fixed sampling regime would have resulted in datasets consisting in large part of duplicates, introducing biases in utility distributions (Katajisto and Moilanen 2006). However, while introducing a fixed sampling regime to decrease biases in how home ranges are used is recommended (de Solla et al. 1999), calculating home range size via KDE does not necessarily require independent data points (Blundell et al. 2001; de Solla et al. 1999; Swihart and Slade 1997). We therefore focused on calculating home range size from the available data, rather than interpreting home range use, but acknowledge that the limited sample sizes may have decreased home range size estimates (see Electronic Supplementary Material [ESM] Fig. S1 for plots of cumulative home range size that illustrate a steep increase in size estimate with fewer nights of data collection).

We compared mean home range size between the wet and the dry season using paired Students $t$-tests (de Winter 2013). We also calculated the percentage of overlap of the $50 \%$ core KDEs (the area an animal is most likely to be found in $50 \%$ of the time) in the 
wet and dry seasons to determine if the study individuals changed their centers of activity over time. We excluded three individuals from this analysis, as they disappeared at the beginning of the dry season and we did not have complete home range data for them.

We could not compare the size of the home ranges for each subseason because of limitations of the datasets. We therefore focused on the daily path length to describe variation in ranging behavior. We calculated daily path length as the distance traveled in meters for each individual for each night of full behavioral observations (18:00 h24:00 h) using the GPS points collected during those nights with the Points-to-Paths plugin in Quantum GIS (Hiatt 2015). We investigated the effect of temperature and subseason on path length over the year with a LMM, setting minimum temperatures measured on days for which path length data were available, sex of the individual, and subseason as fixed effects. As rainfall affects primate ranging behavior (e.g., Ganas and Robbins 2005), we included rainfall (nights with $>5 \mathrm{~mm}$ rainfall vs. those with $<5 \mathrm{~mm}$ rainfall) as a fixed effect. However, this analysis encompasses only nights in which rainfall was light enough to allow full behavioral observations. We also included individual ID and forest area as random effects. We considered only minimum temperatures in the analysis, as these were recorded at night during the active period of the sportive lemurs and may thus have directly influenced activity.

\section{Sleeping Sites}

We calculated the percentage of days each individual was visible at its sleeping sites for each subseason, using the total number of days we recorded the individuals at their sleeping sites. Although we could determine the exact sleeping tree for most days, the study individuals were often not visible, as they often hid in tree holes or foliage, making it impossible to quantify sleeping site types. We plotted the collected GPS points of sleeping sites onto each individual's home range for each season to compare 1) the location and 2) the spread of sites. We calculated the spread of sleeping sites by determining the distance of each sleeping site to the mean GPS location of sleeping sites, the centroid (= standard distance). The centroid is calculated as the mean latitude/ longitude values of sleeping sites for each subseason and individual. Then we investigated the effect of season on the log-transformed standard distances using an LMM, including individual ID and annual home range size as random factors to account for interindividual variation and differences in distance caused by home range size.

We performed all statistical analysis using $\mathrm{R}$ (ver. 3.3.1, R Core Team) using the packages MASS (Venables and Ripley 2002), sp. (Pebesma and Bivand 2005), and raster (Hijmans 2016). We computed home range calculations using the package adehabitatHR (Calenge 2006) and produced all LMMs with the package lme4 (Bates et al. 2015). For all LMMs, we explored the data to ascertain that they met the assumptions of the models. We also reviewed diagnostic plots of residuals. Where we made multiple comparisons, we adjusted $p$-values using the Holm-Bonferroni method. We set the significance level to $P=0.05$ and tests were two-tailed unless stated otherwise.

Data Availability The datasets analysed during the current study are available from the corresponding author on reasonable request. 


\section{Ethical Note}

A team of trained veterinarians captured the study individuals during the daytime at their sleeping sites using nets and anaesthetized each individual with $0.1 \mathrm{ml}$ of Zoletil 100 by hand or using a Telinject blowpipe. The team weighed the subjects and took standard measurements. They equipped captured individuals with a microchip $(8 \mathrm{~mm} \times 1.4 \mathrm{~mm}$ ISO FDXB, Micro-ID, West Sussex, UK) subcutaneously for future identification in case of recapture. We fitted all individuals, eight females and six males, with cable-tie VHF radiocollars that did not exceed $0.7 \%$ of their body mass $(3.5 \mathrm{~g}$, Biotrack, Wareham, UK). We monitored the captured individuals for $\geq 6 \mathrm{~h}$ before releasing them at the capture site at the onset of their normal nocturnal activity period. We also visited all individuals daily and checked for signs of deteriorating health or problems with the collars. At the end of the study period, we recaptured all remaining individuals using the foregoing methods. All subjects had gained mass over the year and all collared females showed signs of pregnancy, indicating that the collars did not prevent mating and reproduction. The veterinarian team removed the remaining collars successfully and released the individuals back into the wild.

We carried out all procedures with ethical approval from the University of Bristol's Ethical Review Group (project number UB/14/048), under the revised Animals (Scientific Procedures) Act 1986, and an approval from Madagascar's Ministère de l'Environnement, de l'Ecologie, de la Mer et des Forets (MEEMF) and Madagascar National Parks (MNP) (permit number 37/16/MEEMF/SG/ DGF/DAPT/SCBT).

The authors declare that they have no conflict of interest.

\section{Results}

\section{Temperature and Rainfall}

Mean minimum and maximum temperatures and rainfall varied across the study period (Fig. 3). Rainfall was highest in January $(612 \mathrm{~mm})$ and February $(>800 \mathrm{~mm})$, dropped markedly in March (302 mm), and ceased in April (Fig. 3). Total rainfall over the data collection period was $2252 \mathrm{~mm}$.

Both minimum and maximum temperatures showed significant differences between the subseasons (Kruskal-Wallis test: $T_{\min }: H=146.21$, $\mathrm{df}=3, p<0.01$; $\left.T_{\max }: H=4.753, \mathrm{df}=3, P<0.01\right)$. Pairwise Mann-Whitney $U$ tests revealed that maximum temperature was significantly lower in the late dry season than in the early dry $(z=-1.91, P=0.05)$ and the late wet season $(z=-3.04, P=0.002)$, despite a drop in maximum temperature during the wet season. Minimum temperature did not differ significantly between the early wet and the late wet seasons, but all other comparisons showed statistically significant differences (early wet-early dry: $\mathrm{z}=-4.91, P<0.01$; early wet-late dry: $z=-7.67$, $P<0.01$; early dry-late dry: $z=-7.01, P<0.01)$ as the temperature decreased over time (Fig. 4). 


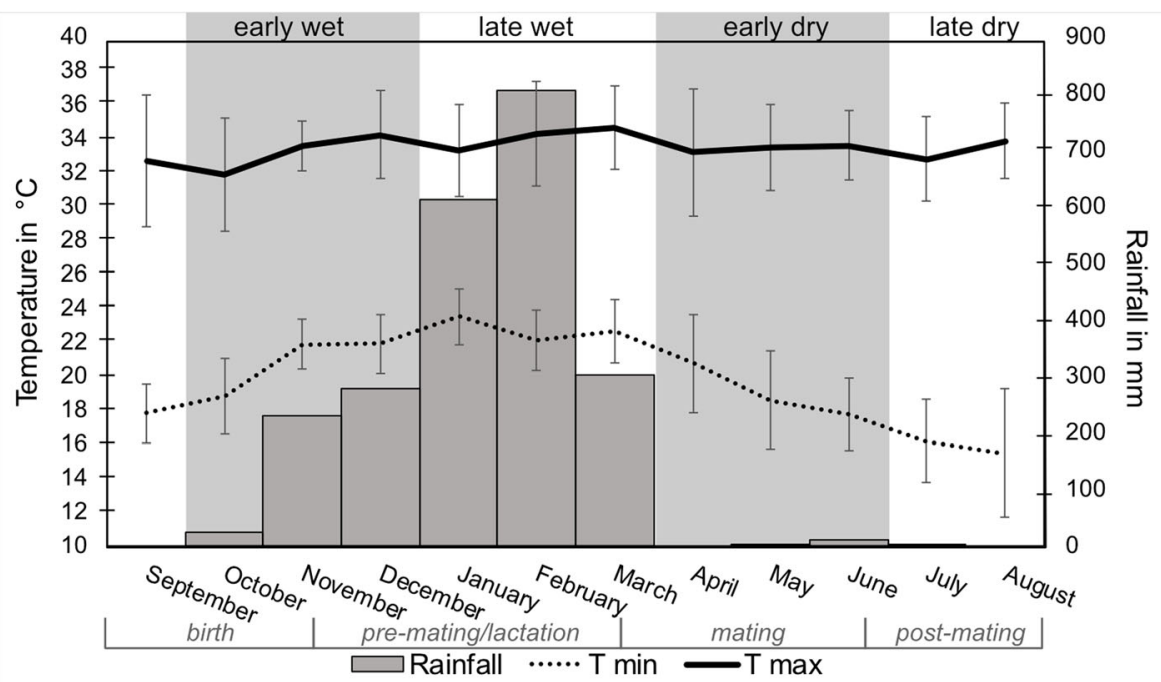

Fig. 3 Mean monthly minimum ( $\mathrm{T}$ min) and maximum temperatures ( $\mathrm{T}$ max) and total monthly rainfall in Ankarafa Forest, Sahamalaza National Park, northwest Madagascar between September 2015 and August 2016 ( $N=322$ measurements). Error bars represent the standard deviation.

\section{Seasonal Effects on Activity Budget}

The study subjects spent a mean of 50\% of their active time Resting Vigilant in all subseasons. Time spent on all other behavioral categories varied across the year (Table IV).

Sex of the study subjects did not have a significant effect on time spent on Locomotion, Resting, Resting Vigilant, Feeding, and Grooming (LMM; Locomotion: $\chi^{2}=0.92, \mathrm{df}=1$, $P=0.34$; Resting: $\chi^{2}=2.04, \mathrm{df}=1, P=0.15$; Resting Vigilant: $\chi^{2}=0.28, \mathrm{df}=1, P=0.59$; Feeding: $\chi^{2}=0.78, \mathrm{df}=1, P=0.38$; Grooming: LMM: $\chi^{2}=3.23, \mathrm{df}=1, P=0.07$ ). Sexes differed only in one behavioral category, with males spending more time on activities categorized as Other (LMM: $\chi^{2}=3.84, \mathrm{df}=1, P=0.04$ ) (see ESM Fig. S2 for more detailed apportionment of different behavioral categories between the sexes across all subseasons).

Subseason did not affect time spent feeding (LMM: $\chi^{2}=7.03, \mathrm{df}=3, P=0.07$ ), nor were there any seasonal influences on time spent Resting Vigilant (LMM: $\chi^{2}=4.84, \mathrm{df}=3$, $P=0.18$ ) or behaviors classed as Other (LMM: $\chi^{2}=2.31, \mathrm{df}=3, P=0.51$ ). We found a significant seasonal effect on Grooming (LMM: $\chi^{2}=7.96, \mathrm{df}=3, P=0.04$ ) but post hoc comparisons revealed no statistically significant differences between individual subseasons.

Locomotion was significantly affected by subseason (LMM: $\chi^{2}=77.74, \mathrm{df}=3$, $P<0.01)$ : Tukey post hoc pairwise comparisons indicated that locomotion was highest in the late wet season compared to the rest of the year (late wet-early wet: $z=2.6, P=$ 0.4 ; late wet-early dry: $z=-3.4, P<0.01$; late wet-late dry: $z=-7.1, P<0.01$ ) while the

Fig. 4 Daily maximum and minimum temperatures $(N=322$ measurements) in Ankarafa Forest, Sahamalaza National Park, northwest Madagascar, across four subseasons. Letters indicate statistically significant different values at $P<0.05$, based on a Kruskal-Wallis analysis of variance. NS = nonsignificant. Black bars depict the median, gray boxes the upper and lower quartiles, and whiskers the range. 

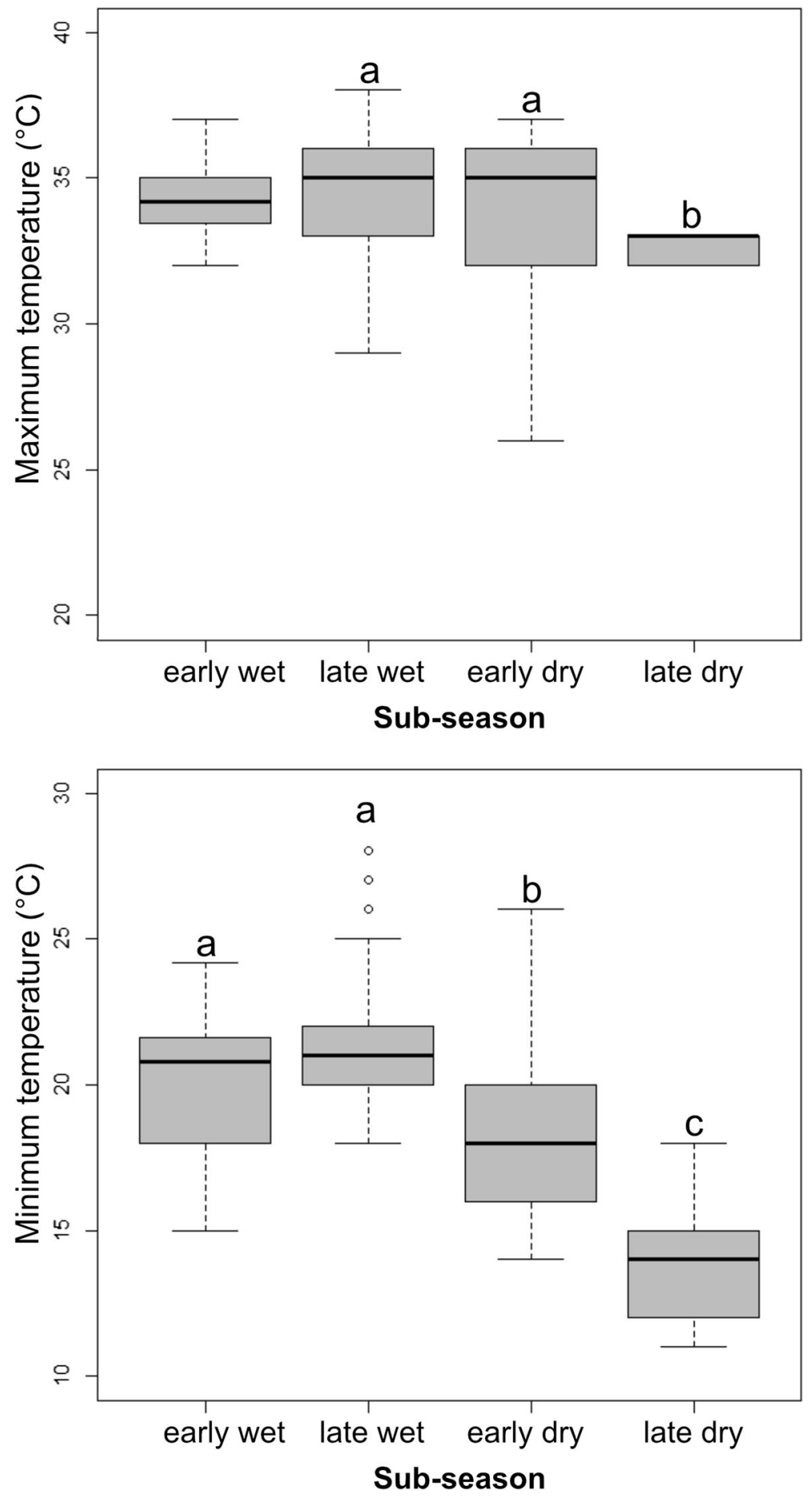


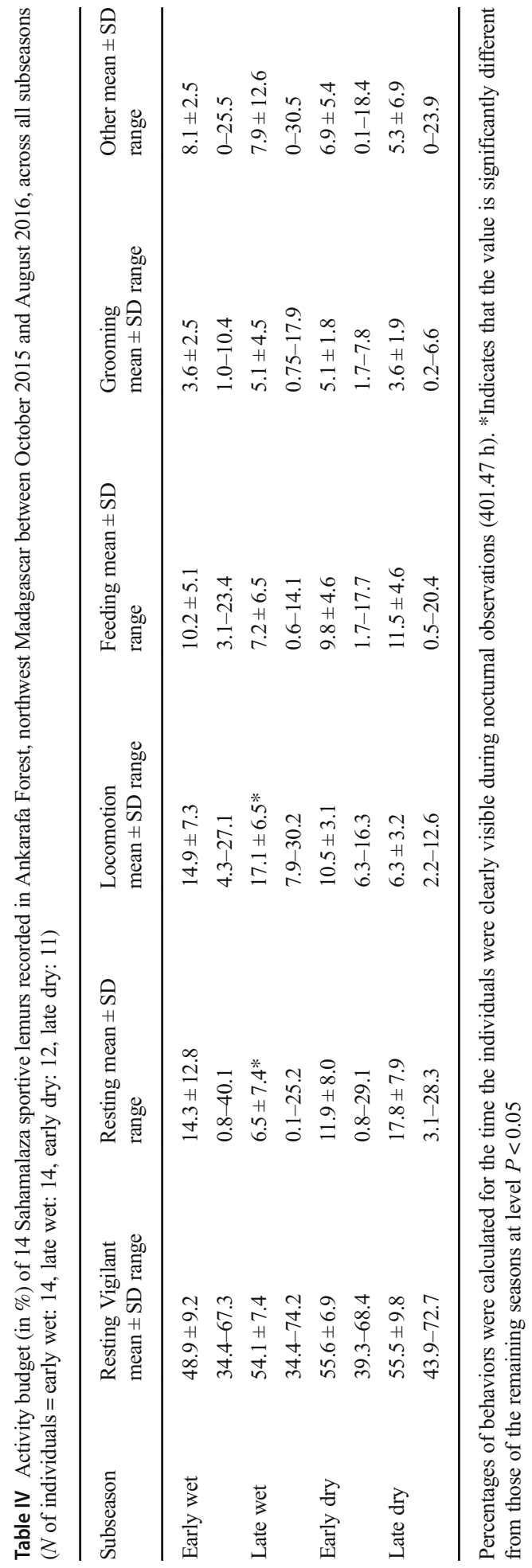


study individuals spent the least amount of time with locomotion during the late dry season (late dry-early wet: $z=-4.5, P<0.01$; late dry-early dry: $z=-3.8, P<0.01$ ) (Fig. 5). Similarly, subseason had a significant effect on the time spent Resting (LMM: $\chi^{2}=$ 22.57 , df $=3, P<0.01$ ), and study individuals spent significantly less time resting in the late wet season than during any other period (late wet-early wet: $z=-2.8, P=0.02$; late wet-early dry: $z=2.7, P=0.03$; late wet-late dry: $z=4.1, P<0.01$ ) (Fig. 5). The interactions between sex and subseason showed no statistical significance in any recorded behavior (Locomotion: LMM: $\chi^{2}=4.66, \mathrm{df}=3, P=0.19$; Resting: LMM: $\chi^{2}=1.01, \mathrm{df}=3, P=$ 0.79; Resting Vigilant: LMM: $\chi^{2}=0.74, \mathrm{df}=3, P=0.86$; Feeding: LMM: $\chi^{2}=1.51, \mathrm{df}=$ 3, $P=0.67$; Grooming: LMM: $\chi^{2}=0.74, \mathrm{df}=3, P=0.86$; Other: LMM: $\chi^{2}=1.77, \mathrm{df}=3$, $P=0.62)$.

\section{Seasonal Effects on Home Range Size and Ranging}

There was no difference in the size of the home ranges (overall size mean \pm SD: $0.67 \pm$ 0.53 ha, range: $0.22-1.4 \mathrm{ha}$ ) between the wet and the dry season (paired Student's $t$ test: $t=$ $-0.13, \mathrm{df}=10, P=0.86$ ). Overlap of the $50 \%$ core areas between the wet and the dry season was $26.8 \pm 18.8 \%$ (mean $\pm \mathrm{SD}$, range: $7.6-67.9 \%$ ).

Path length was not significantly affected by subseason (LMM: $\chi^{2}=2.16$, $\mathrm{df}=3, P=$ 0.53 ) or sex (LMM: $\chi^{2}=0.38, \mathrm{df}=31, P=0.54$ ) (Fig. 6). The effect of minimum temperature was nonsignificant (LMM: $\left.\chi^{2}=2.7, \mathrm{df}=3, P=0.09\right)$ and rainfall affected path length significantly (LMM: $\chi^{2}=4.66, \mathrm{df}=1, P=0.03$ ). Lemurs traveled shorted distances on nights with rainfall $>5 \mathrm{~mm}$ than on nights with $<5 \mathrm{~mm}$.

\section{Seasonal Effects on Sleeping Site Choice}

The visibility of the study individuals during the day varied between seasons (Table V). Sleeping sites were usually either liana tangles, cavities in dead and living trees, in palm leaves, or simply on branches. Some individuals used the same trees repeatedly year-round. Cavities in dead or living trees were used mainly during the colder months (I. Mandl pers. $o b s$.). These cavities fulfilled a double function: the exposed entry hole enabled sunbathing, while the cavity was often deep enough for the individual to fully hide from predators. However, as we could not see individuals in their sleeping trees for $31.6 \%$ of the days we recorded them, we could not quantify the number of different sleeping site types.

Over the study period, each study subject used multiple sleeping sites located in different areas of their home ranges (Fig. 7). The distance to the spatial centroid was affected by subseason (LMM: $\left.\chi^{2}=99.43, \mathrm{df}=3, P<0.01\right)$. Sites were further apart in the late wet $(z=$ $-9.7, P<0.01)$ and early dry season $(z=-6.7, P<0.01)$ than in the late dry season (Tukeyadjusted, post hoc pairwise comparisons), when study individuals used sleeping sites in a limited area of their home range (Fig. 8).

\section{Discussion}

Temperature and rainfall in the study region varied considerably over the study period of $10 \mathrm{mo}$, with the late dry season showing the lowest temperatures. Rainfall occurred mainly between October and March. Sportive lemurs showed few sex differences in 

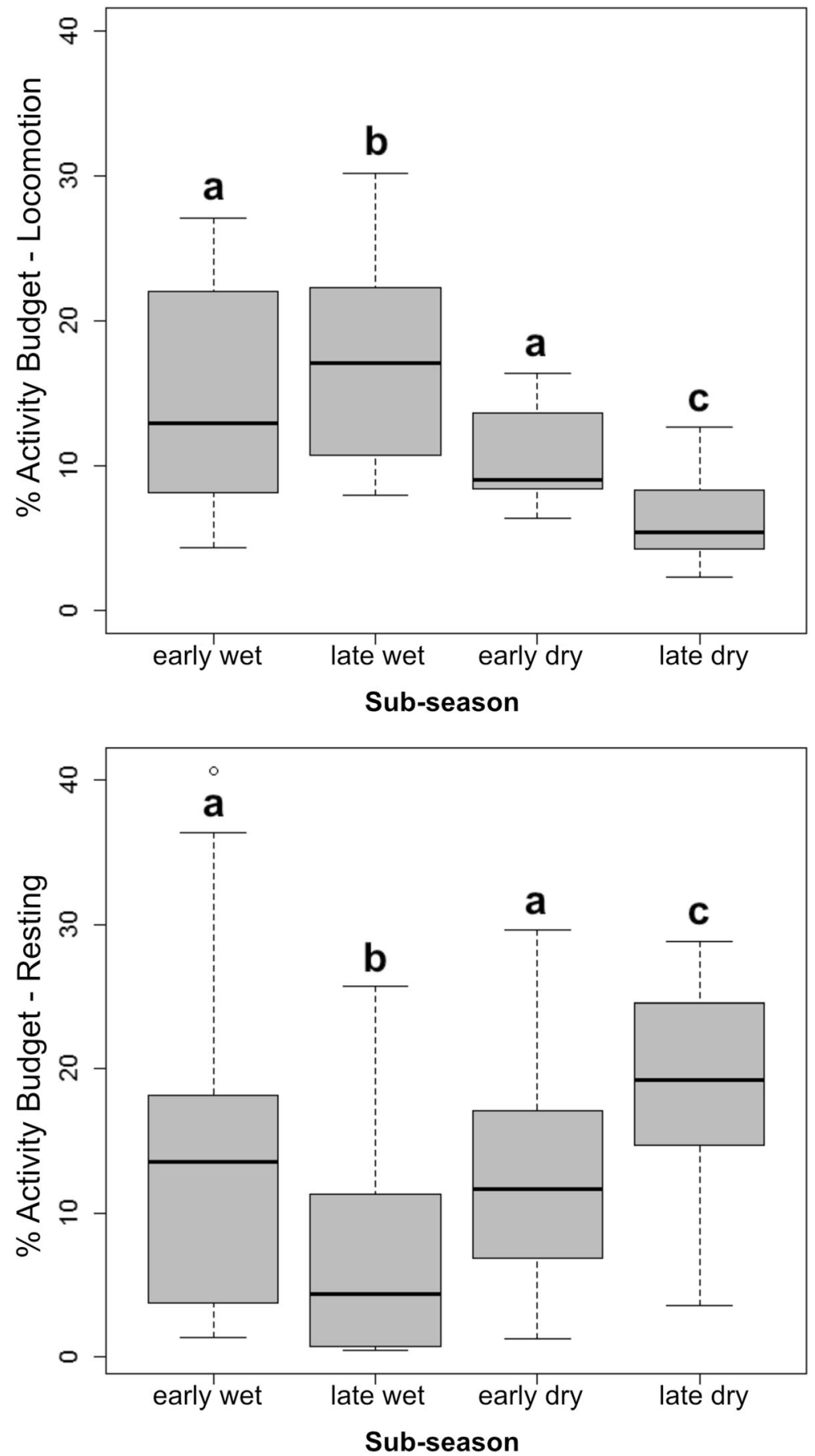
Fig. 5 Percentage of time Sahamalaza sportive lemurs ( $N=$ early wet: 14 ; late wet: 14 ; early dry: 12 ; late dry: 11) in Ankarafa Forest, Sahamalaza National Park, northwest Madagascar, spent on locomotion and resting behaviour between October 2015 and August 2016 by subseason. Letters indicate statistically significant different values at $P<0.05$. Black bars depict the median, the gray boxes the upper and lower quartiles, and whiskers the range.

behavior and only locomotive and resting behaviors differed significantly between subseasons. Time spent feeding increased over the dry season, but this was not statistically significant. There were no measurable differences in the sizes of home ranges between the dry and the wet season, but rainfall significantly negatively affected ranging behavior. While we could not record the number and types of sleeping sites, the locations of sleeping trees varied across subseasons, with wider spread of sleeping sites in the late wet season than the rest of the year.

\section{Seasonal Effects on Activity Budget}

As we predicted, Sahamalaza sportive lemurs rested more and traveled less in the coldest period of the year. Across all seasons, Resting Vigilant made up nearly half of the activity budget, in line with previous studies that showed that this species remains stationary for prolonged periods at night (Seiler et al. 2014). However, time spent resting increased significantly in the coldest period.

These findings mirror what previous studies suggested to be a strategy for energy conservation during times of low resource abundance (e.g., Eppley et al. 2016; Ganzhorn et al. 2004; Nowack et al. 2013). The lemurs fed on the leaves of $>40$ different species of plants in previous studies (Seiler et al. 2014). During the present study, they added fruit to their diet in the wet season, but leaves constituted most of the diet year-round (I. Mandl pers. obs.) as observed in other folivorous primate species such as mantled howler monkeys

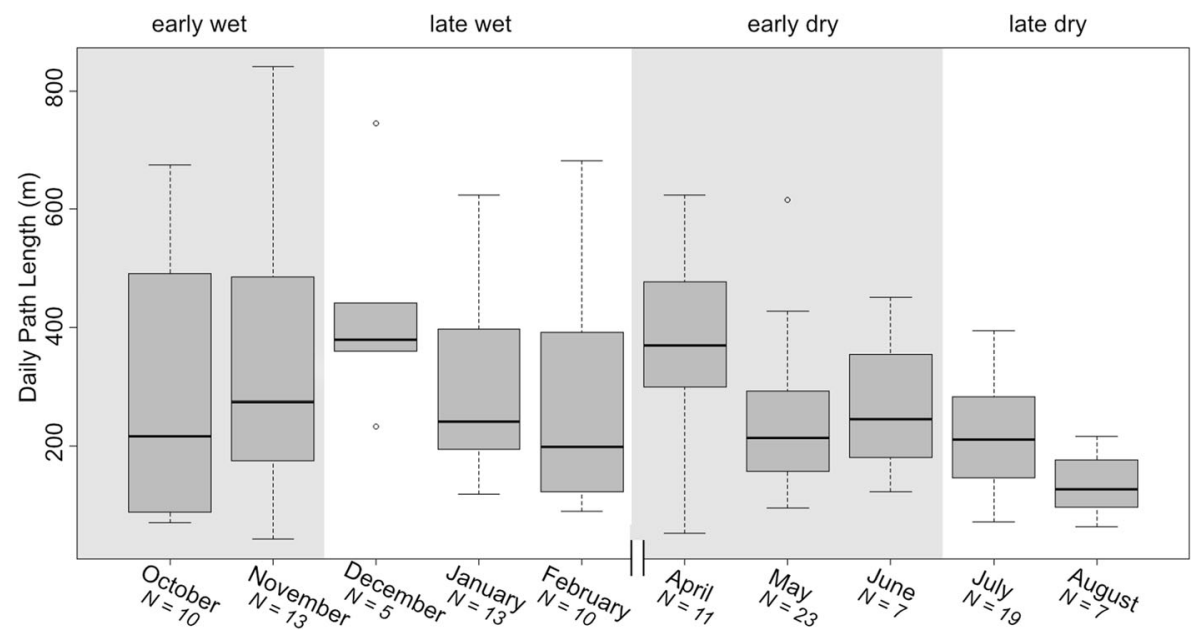

Fig. 6 Daily path lengths of 14 Sahamalaza sportive lemurs ( $N=$ early wet: 14 ; late wet: 14 ; early dry: 12; late dry: 11 individuals), recorded in Ankarafa Forest, Sahamalaza National Park, northwest Madagascar between October 2015 and August 2016 by month of data collection and subseason. No data collection in March. Black bars depict the median, gray boxes the upper and lower quartiles, and whiskers the range. 
Table V Percentage of days on which radio-collared Sahamalaza sportive lemurs $(N=14)$ were visible/not visible during sleeping site checks in Ankarafa Forest, northwest Madagascar between October 2015 and August 2016, by subseason

\begin{tabular}{llll}
\hline Subseason & GPS points recorded & Not visible (\%) & Visible (\%) \\
\hline Early wet & 238 & 22.3 & 77.7 \\
Late wet & 287 & 45.3 & 54.7 \\
Early dry & 302 & 29.1 & 70.9 \\
Late dry & 175 & 26.9 & 73.1 \\
\hline
\end{tabular}

GPS points are the locations of sleeping sites that we could determine. We found individuals classed as "not visible" using their radio-collars but could not see them clearly

(Alouatta palliate: Dunn et al. 2010), bushbabies (Galago spp.: Harcourt 1986), Cat Ba langurs (Trachypithecus poliocephalus: Hendershott et al. 2016), Japanese macaques (Macaca fuscata yakui: Hill 1997), diademed sifaka (Propithecus diadema: Irwin et al. 2014), black howler monkeys (A. pigra: Pozo-Montuy and Serio-Silva 2007),
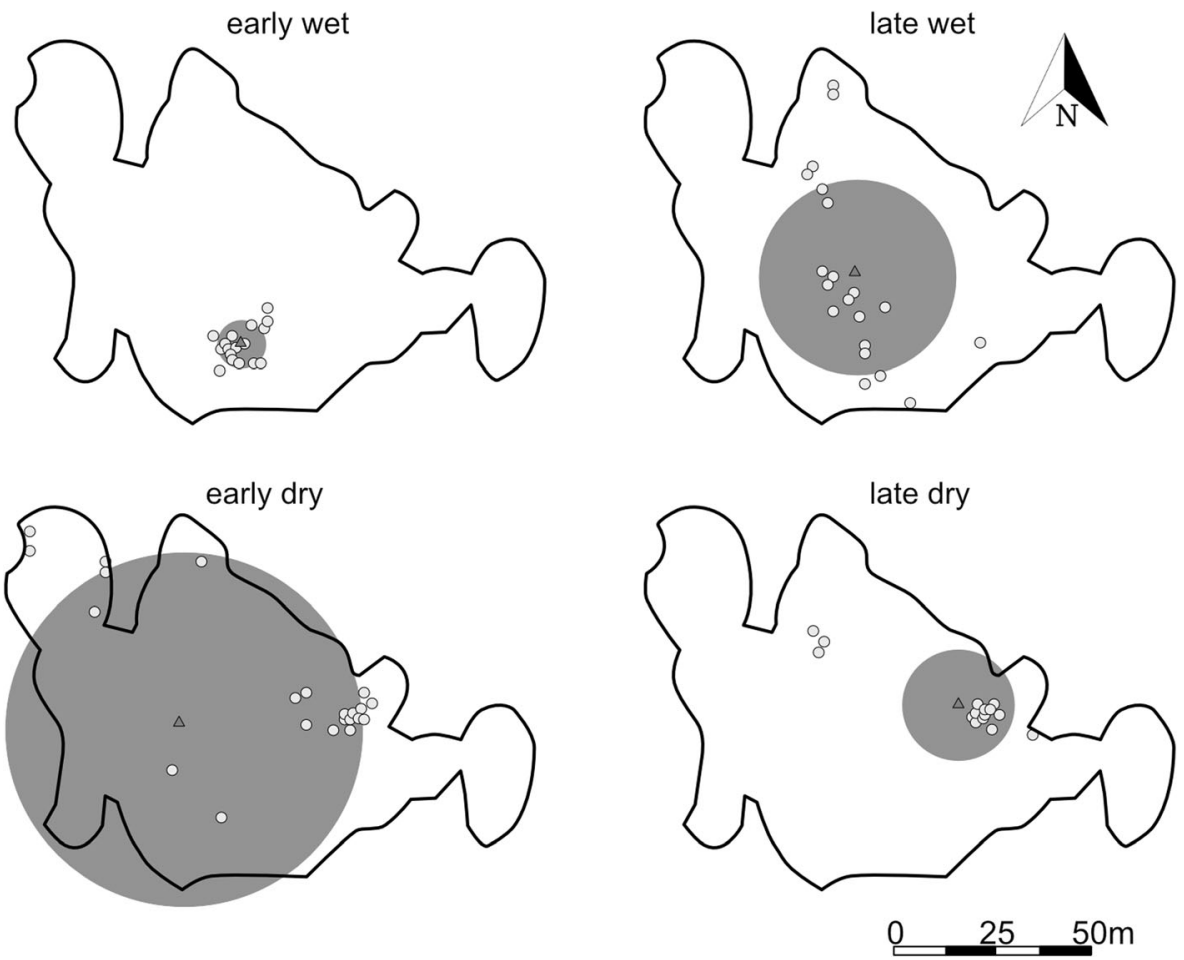

Fig. 7 The location of sleeping sites in each subseason for one Sahamalaza sportive lemur (12 M) recorded in Ankarafa Forest, Sahamalaza National Park, northwest Madagascar between October 2015 and August 2016. The black outline represents the annual home range $(99 \% \mathrm{KDE})$; gray dots individual sleeping site locations ( $N=$ early wet: 17 , late wet: 21 , early dry: 29 , late dry: 16 ). Triangles illustrate the spatial centroids and the radius of the gray-shaded circles around the spatial centroids the mean standard distance for each subseason (early wet: $5.9 \mathrm{~m}$; late wet: $23.6 \mathrm{~m}$; early dry: $45.7 \mathrm{~m}$; late dry: $15.8 \mathrm{~m}$ ). Early wet=October/November/ December; late wet $=$ January/February; early dry = April/May/June; and late dry $=$ July/August. 


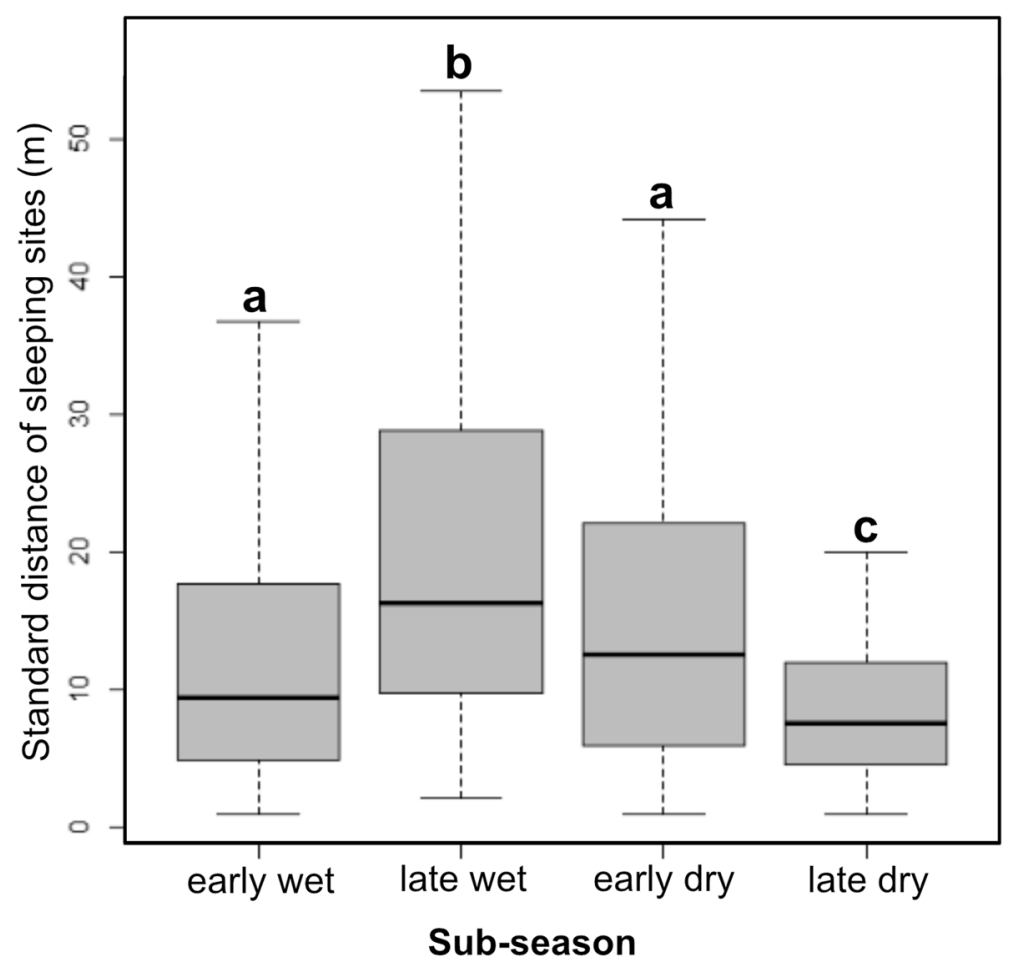

Fig. 8 Distance between individual sleeping sites and mean sleeping site location for 14 individual Sahamalaza sportive lemurs ( $N=$ early wet: 14 ; late wet: 14 ; early dry: 12 ; late dry: 11$)$ recorded in Ankarafa Forest, Sahamalaza National Park, northwest Madagascar between October 2015 and August 2016, for each subseason. Letters indicate statistically significant differences at $P<0.01$. Black bars depict the median, gray boxes the upper and lower quartiles, and whiskers the range.

brown lemurs (Eulemur fulvus: Sato et al. 2014), and rhesus macaques (M. mulatta: Tang et al. 2016; van Schaik and Brockman 2005). More long-term studies on phenology and nutrition are needed to determine to what extent Sahamalaza sportive lemurs are subjected to resource fluctuations, but findings fail to support the idea that the coldest period signifies the environmentally most stressful time due to food limitations for red-tailed sportive lemurs (Lepilemur ruficaudatus: Ganzhorn 2002). White-footed sportive lemurs (L. leucopus) decreased activity levels in the coldest period of the year while leaves were still abundant and increased again with increasing ambient temperatures, when food availability reached a low point (Dröscher and Kappeler 2014). The authors suggest that minimum temperatures affected energy expenditure more than fluctuations in dietary resources. An increase in food intake, hypothesized to fuel heat production during the dry season, further points toward behavioral adaptations to cold temperatures (Dröscher et al. 2016). The sportive lemurs in our study increased the proportion of time spent feeding during the colder periods, but this effect was not statistically significant and data on resource availability are needed to conclude whether increased time spent feeding reflects a compensatory behavior for a diet of lesser quality (e.g., Hendershott et al. 2016) or a thermoregulatory strategy (e.g., Nowack et al. 2013). A further seasonal adaptation in feeding behavior is a change in nutrient composition of the diet: white-footed sportive lemurs increased nonprotein (e.g., fiber) intake during the dry season, possibly owing to variations in available foods (Dröscher 
et al. 2016). Diets high in fiber can affect heat production (Zhao and Wang 2007), further inducing thermoregulatory stress, but more research is needed to investigate the intertwined effects of high-fiber, folivorous diets and thermoregulation in primates.

A change in proportion of resting to traveling has been suggested to be a thermoregulatory strategy in other small, nocturnal primate species (Knox and Wright 1989; Schmid and Kappeler 2005). Behavioral thermoregulation to counteract cold stress can include a decrease in active behavior, positional changes (e.g., "hunched" posture while resting; Dagosto 1995) or social huddling during the day and night (Gilbert et al. 2010; Ostner 2002). During the present study, a female spent $3 \mathrm{~h}$ huddling with an unknown, but likely younger because smaller, individual during a particularly cold night, possibly to minimize heat loss, as in a wide range of endothermic animals (Gilbert et al. 2010; Kotze et al. 2008; Ostner 2002; Savagian and Fernandez-Duque 2017). Huddling effects physiological changes in mouse lemurs, Microcebus murinus, decreasing metabolic costs and thus conserving energy (Perret 1998). Sportive lemurs have low resting and basal metabolic rates, like other strepsirrhines (Bethge et al. 2017; Dorcas and Crompton 1998; Schmid and Ganzhorn 1996; Wright 1989, 1999). The sportive lemurs' low metabolic rate and long resting bouts during the dry season may be in part due to physiological thermoregulation (Bethge et al. 2017; Kobbe et al. 2014; Kurland and Pearson 1986; Schülke and Ostner 2007; Sparrow and Newell 1998). However, more research is required to fully understand the effects of temperature fluctuations on sportive lemur physiology (see Bethge et al. 2017).

The sexes did not differ in the times they allocated to resting and traveling behaviors across the year. Overall males groomed less than females but engaged more in activities of the category "Other" owing to their increased vocal activity compared to females (unpubl. data). These results indicate that males and females did not face different energetic demands despite the additional requirements of lactation and gestation in females, in accordance with what has been found for white-footed sportive lemurs (Dröscher et al. 2016), ring-tailed lemurs (Lemur catta), and brown lemurs (Eulemur sp.: Simmen et al. 2010).

\section{Seasonal Effects on Ranging Behavior}

We predicted a change in home range size between the warmer wet and colder dry seasons, reflecting decreased activity in the colder period of the year. The home range sizes recorded in this study were in line with what has been reported previously for this species (Seiler et al. 2015) but did not differ between the seasons. In addition, home range locations did not change considerably between the seasons, in contrast to those of primates that rely on fruiting trees year-round and change their ranges to incorporate available fruit (Garber 1993; Peres 1994; Wallace 2006). Home range size, and possibly location, differs between seasons if habitat requirements differ (e.g., Wiktander et al. 2001), which may not be the case for the folivorous Sahamalaza sportive lemur (Seiler et al. 2014).

The lemurs traveled shorter distances in nights with rainfall, which occurred mainly between December and February. Rainfall can affect the insulation properties of fur, reducing its thermal resistance (Webb and King 1984). The Sahamalaza sportive lemurs 
in this study may have sought to avoid getting wet by remaining in shelter during rain bouts. Variation in path length as a response to rising humidity levels has also been reported in other primate species: in gorillas (Gorilla beringei) shorter path lengths are associated with increase in humidity and rainfall (Ganas and Robbins 2005), whereas Javan slow lorises (Nycticebus javanicus) travel more in a more humid environment (Reinhardt et al. 2016).

The sex of the lemur did not affect path length, although the sexes have potentially different reproductive interests as males may roam to find receptive females (Lane et al. 2010). These findings reflect those for red-tailed sportive lemurs (Ganzhorn et al. 2004). Distance traveled also did not differ between the subseasons in this study: while individuals decreased the time spent in locomotion, they did not travel shorter distances. Shorter path lengths may reflect either a change in resource distribution (e.g., Hoffman and O'Riain 2011) or an adaptation to conserve energy in a climate with extreme temperatures (hot: e.g., Campos and Fedigan 2009; cold: Ganzhorn et al. 2004; Warren and Crompton 1997). Red-tailed sportive lemurs (Ganzhorn et al. 2004), red-ruffed lemurs (Varecia rubra: Vasey 2005), howler monkeys (Alouatta caraya: Raño et al. 2016), snub-nosed monkeys (Rhinopithecus bieti: Ren et al. 2009), and Phayre's leaf monkeys (Trachypithecus phayrei: Carl 2009), all travel less in the coldest time of the year. Although heat production is generally fueled by locomotion, traveling can be energetically costly (Terrien et al. 2011), especially for species with low metabolic rates, such as sportive lemurs. However, the energetic costs of locomotive behavior in this genus have not been studied in depth (Dorcas and Crompton 1998; Warren and Crompton 1997). It is possible that colder temperatures have an additional constraining effect on primate movement, as heat may be lost through exposure of less insulated body areas (Paterson 1983). In contrast, white-faced capuchins (Cebus capucinus) reduce path length with increasing temperatures (Campos and Fedigan 2009). These primates reduced their travel distances and centred their activities around remaining water sources in hotter temperatures (Campos and Fedigan 2009). While the sportive lemurs we studied may also have been influenced by variation in resource distribution, the unequal sample sizes and variances in the data set did not allow for further analysis of path length. More detailed information is needed to determine the variability of environmental resources for this species.

\section{Seasonal Effects on Sleeping Site Choice}

Based on previous results that the lemurs did not use tree holes after days with rainfall (Seiler et al. 2013), we predicted a difference in sleeping sites between subseasons. As the study subjects were hidden at their sleeping sites for at least a quarter of the days that GPS points were collected, we did not analyze the number and types of sleeping sites. A previous study indicated that microhabitats around sleeping sites are important to this species, suggesting only specific sleeping sites meet ecological needs (Seiler et al. 2013). The changes in sleeping site locations recorded in the present study may imply differing requirements or priorities (e.g., protection from rain) across the year. The lemurs used sleeping site locations that were spread over a greater area during the late wet season than the rest of the year. Lemurs may have sought more sheltered places during months with heavy rains, as suggested by Seiler et al. (2013): some of the tree cavities used during the dry season were very exposed and even collected water during 
the wet season (I. Mandl pers. obs.). This could explain the fact that the study individuals were least visible during sleeping site checks between December and February, the months with the highest rainfall, as they rested in well-covered day sleeping sites. However, this does not sufficiently explain why the study individuals slept in multiple locations spaced more widely apart, rather than staying in one or two well-sheltered sites.

Suitable sleeping sites may represent a limited resource, as suggested for Milne Edwards' sportive lemurs, (Lepilemur edwardsi: Rasoloharijaona et al. 2003) and weasel sportive lemurs (L. mustelinus: Rasoloharijaona et al. 2010). The importance of high-quality sleeping sites that provide sufficient protection from predators and weather has been emphasized (Anderson 1998). Using sleeping sites far apart and changing them often can function in predator avoidance (Hrdy 1980; Smith et al. 2007): small-bodied primates such as tufted capuchins (Sapajus apella), moustached tamarins (Saguinus imperator), and Azara's owl monkeys (Aotus azarae) change sleeping sites frequently and avoid sleeping in the same location on consecutive nights, presumably to prevent predators from anticipating sleeping site locations (di Bitetti et al. 2000; Savagian and Fernandez-Duque 2017; Smith et al. 2007). We did not assess the predation pressure on sportive lemurs by raptors (e.g., Madagascar harrier hawk, Polyboroides radiatus), snakes (e.g., boas, Acrantophis madagascariensis), or carnivores (e.g., fossa, Cryptoprocta ferox) in the study area but predation pressure was higher during the dry season than the rest of the year in previous studies conducted in similar habitats (Gursky and Nekaris 2007; Rasmussen 2005; Schnoell and Fichtel 2011). Our study subjects slept in a limited area of their home range during the late dry season (July and August), using only one or two sleeping sites repeatedly. They often rested in very exposed spots, as recorded by the high visibility in this period. Sahamalaza sportive lemurs were easily found, often resting exposed, during the dry season in a previous study that showed that this species was highly vigilant and reactive toward calls of predators, regardless of sleeping site type (Seiler et al. 2013). Sleeping sites chosen in the dry season may provide increased protection from predators by enabling earlier detection in a more exposed resting place (Gursky and Nekaris 2007).

The lemurs we studied may also use dry season sleeping sites based on other factors, such as ambient temperature: colder temperatures induce animals to choose sleeping sites that provide them with thermoregulatory benefits such as better insulation (Karanewsky and Wright 2015; Radespiel et al. 1998) or sun exposure. Azara's owl monkeys face similar trade-offs and choose sleeping sites to minimize predation risk while being constrained by thermoregulatory requirements (Savagian and FernandezDuque 2017). These primates rest in more exposed places during colder periods, enabling sunbathing behavior - a possible parallel to Sahamalaza sportive lemurs, which remain active during the day, changing position frequently but not leaving their sleeping sites (Ruperti 2007; Seiler et al. 2013). Colder temperatures at night may have induced the lemurs to rest in exposed sites that allow for sunbathing to rewarm faster as in the marsupial fat-tailed antechinus (Pseudantechinus macdonnellensis: Geiser et al. 2002). Suitable, sun-exposed sleeping sites that provide protection from predators may be limited in the colder period of the year, which may explain why the lemurs returned to the same one or two locations during the late dry season.

The spread in sleeping site locations may have been influenced by social drivers: sleeping sites used during the late wet season, which coincides with the premating 
period, were furthest apart and located in multiple places within the home range, some especially close to the borders. During such periods, the study individuals may have sought to mark their territories by sleeping in and marking multiple locations (Day and Elwood 1999; Reichard 1998; Singhal et al. 2007).

In conclusion, Sahalamaza sportive lemurs showed seasonal changes in activity budgets and sleeping site locations, as well as fluctuations in travel distances across the year. The underlying drivers of seasonally changing behavior remain to be studied in detail. Future studies should also aim to understand variation in sportive lemur ecology, in particular 1) the physiological adaptations of this genus to strong temperature fluctuations, 2) the trade-off between predation pressure and thermoregulatory requirements, and 3) the nutrient requirements and feeding behavior across all season.

Our results reflect findings from studies of other primate taxa: seasonal changes in climate, and accompanying resource abundance, influence primate behavioral ecology (Hemingway and Bynum 2005). Primates display behavioral flexibility and energy-conserving behavior when faced with environmental stressors such as low food availability or temperature fluctuations (van Schaik and Brockman 2005). In view of expected long-term changes in global climate, research on the tolerance and degree of flexibility across primates is required to anticipate species' reactions (Beever et al. 2017).

Acknowledgments The authors would like to thank the Institute for the Conservation of Tropical Environments (ICTE) for their facilitation services, as well as Madagascar National Parks (MNP) and Madagascar's Ministère de l'Environnement, de l'Ecologie, de la Mer et des Forets (MEEMF) for permission to conduct research in the protected area. They would also like to thank Guy Randriatahina and the Association Européenne pour l'Etude et la Conservation des Lémuriens (AEECL) for continued support during field work. Special thanks to Naina Rabemananjara and multiple field assistants who substantially contributed to the data collection during field work, and the editors as well as three anonymous reviewers for their comments and suggestions on the manuscript. This study was funded by the Primate Society of Great Britain, the Explorer's Club Student Grant, Pittsburgh Zoo and PPG Aquarium Sustainability Fund, Primate Conservation Inc., Fresno Chaffee Zoo and Wildlife Conservation Fund, Minnesota Zoo's Ulysses S. Seal Conservation Grant and the Primate Action Fund. I. Mandl conceived and designed the study, collected and analyzed the data, and wrote the manuscript; M. Holderied and C. Schwitzer revised the manuscript and provided editorial advice.

Open Access This article is distributed under the terms of the Creative Commons Attribution 4.0 International License (http://creativecommons.org/licenses/by/4.0/), which permits unrestricted use, distribution, and reproduction in any medium, provided you give appropriate credit to the original author(s) and the source, provide a link to the Creative Commons license, and indicate if changes were made.

\section{References}

Addo-Bediako, A., Chown, S. L., \& Gaston, K. J. (2000). Thermal tolerance, climatic variability and latitude. Proceedings of the Royal Society of London B: Biological Sciences, 267, 739-745.

Anderson, J. R. (1998). Sleep, sleeping sites, and sleep-related activities: Awakening to their significance. American Journal of Primatology, 46, 63-75.

Andriaholinirina, N., Fausser, J.-L., Roos, C., Zinner, D., Thalmann, U., et al (2006). Molecular phylogeny and taxonomic revision of the sportive lemurs (Lepilemur, Primates). BMC Evolutionary Biology, 6, 17.

Andriaholinirina, N., Fausser, J.-L., Roos, C., Zinner, D., Thalmann, U., et al (2017). Corrective paper concerning three new species of the genus Lepilemur Geoffroy, 1851 (Mammalia). Dumerilia, 7, 62-71. 
Aujard, F., Perret, M., \& Vannier, G. (1998). Thermoregulatory responses to variations of photoperiod and ambient temperature in the male lesser mouse lemur: A primitive or an advanced adaptive character? Journal of Comparative Physiology B, 168, 540-548.

Bates, D., Maechler, M., Bolker, B., \& Walker, S. (2015). Fitting linear mixed-effects models using lme4. Journal of Statistical Software, 67(1), 1-48.

Beever, E. A., Hall, L. E., Varner, J., Loosen, A. E., Dunham, J. B., et al (2017). Behavioral flexibility as a mechanism for coping with climate change. Frontiers in Ecology and the Environment, 15(6), 299-308.

Bethge, J., Wist, B., Stalenberg, E., Dausmann, K. (2017) Seasonal adaptations in energy budgeting in the primate Lepilemur leucopus. Journal of Comparative Physiology B, 187(5-6):827-834.

Blanco, M. B., \& Rahalinarivo, V. (2010). First direct evidence of hibernation in an eastern dwarf lemur species (Cheirogaleus crossleyi) from the high-altitude forest of Tsinjoarivo, Central-Eastern Madagascar. Naturwissenschaften, 97, 945-950.

Blundell, G. M., Maier, J. A. K., \& Debevec, E. M. (2001). Linear home ranges: Effects of smoothing, sample size, and autocorrelation on kernel estimates. Ecological Monographs, 71(3), 469-489.

Brockman, D. K., \& van Schaik, C. P. (Eds.) (2005). Seasonality in primates: Studies of living and extinct human and non-human primates. Cambridge: Cambridge University Press.

Calenge, C. (2006). The package adehabitat for the R software: A tool for the analysis of space and habitat use by animals. Ecological Modelling, 197, 516-519.

Campera, M., Serra, V., Balestri, M., Barresi, M., Ravaolahy, M., et al (2014). Effects of habitat quality and seasonality on ranging patterns of collared brown lemur (Eulemur collaris) in littoral forest fragments. International Journal of Primatology, 35, 957-975.

Campos, F. A., \& Fedigan, L. M. (2009). Behavioral adaptations to heat stress and water scarcity in whitefaced capuchins (Cebus capucinus) in Santa Rosa National Park, Costa Rica. American Journal of Physical Anthropology, 138, 101-111.

Carl, K. M. (2009). Home range size, daily path length, and territoriality in Phayre's leaf monkeys (Trachypithecus phayrei). Masters thesis, Stony Brook University.

Craul, M., Zimmermann, E., Rasoloharijaona, S., Randrianambinina, B., \& Radespiel, U. (2007). Unexpected species diversity of Malagasy primates (Lepilemur spp.) in the same biogeographical zone: A morphological and molecular approach with the description of two new species. BMC Evolutionary Biology, 7 , 83 .

Dagosto, M. (1995). Seasonal variation in positional behavior of Malagasy lemurs. International Journal of Primatology, 16(5), 807-833.

Dausmann, K. H., Glos, J., Ganzhorn, J. U., \& Heldmaier, G. (2004). Hibernation in a tropical primate. Nature, 429, 825-827.

Day, R. T., \& Elwood, R. W. (1999). Sleeping site selection by the golden-handed tamarin Saguinus midas midas: The role of predation risk, proximity to feeding sites, and territorial defence. Ethology, 105(12), 1035-1051.

de Gouvenain, R. C., \& Silander, J. A. (2003). Do tropical storm regimes influence the structure of tropical lowland rain forests? Biotropica, 35(2), 166-180.

de Solla, S. R., Bonduriansky, R., \& Brooks, R. J. (1999). Eliminating autocorrelation reduces biological relevance of home range estimates. Journal of Animal Ecology, 68, 221-234.

de Winter, J. C. F. (2013). Using the Student's $t$-test with extremely small sample sizes. Practical Assessment, Research \& Evaluation, 18(10), 1-12.

di Bitetti, M. S., Vidal, E. M. L. V., Baldovino, M. C., \& Benesovsky, V. (2000). Sleeping site preference in tufted capuchin monkeys (Cebus apella nigritus). American Journal of Primatology, 50, 257-274.

Donati, G., Ricci, E., Baldi, N., Morelli, V., \& Borgognini-Tarli, S. M. (2010). Behavioral thermoregulation in a gregarious lemur Eulemur collaris: Effects of climatic and dietary-related factors. American Journal of Physical Anthropology, 1, 1-10.

Dorcas, R. D., \& Crompton, R. H. (1998). Diet, body size and the energy costs of locomotion in saltatory primates. Folia Primatologica, 69, 86-100.

Dröscher, I., \& Kappeler, P. M. (2014). Competition for food in a solitarily foraging folivorous primate (Lepilemur leucopus)? American Journal of Primatology, 76, 842-854.

Dröscher, I., Rothman, J. M., Ganzhorn, J. U., \& Kappeler, P. M. (2016). Nutritional consequences of folivory in a small-bodied lemur (Lepilemur leucopus): Effects of season and reproduction on nutrient balancing. American Journal of Physical Anthropology, 160, 197-207.

Dumetz, N. (1999). High plant diversity of lowland rainforest vestiges in eastern Madagascar. Biodiversity and Conservation, 8, 273-315.

Dunn, J. C., Cristóbal-Azkarate, J., \& Veà, J. J. (2010). Seasonal variations in the diet and feeding effort of two groups of howlers in different sized forest fragments. International Journal of Primatology, 31, 887-903. 
Eppley, T. M., Donati, G., \& Ganzhorn, J. U. (2016). Determinants of terrestrial feeding in an arboreal primate: The case of the southern bamboo lemur (Hapalemur meridionalis). American Journal of Physical Anthropology, 161, 328-342.

Fietz, J., \& Dausmann, K. H. (2006). Big is beautiful: Fat storage and hibernation as a strategy to cope with marked seasonality in the fat-tailed dwarf lemur (Cheirogaleus medius). In L. Gould \& M. L. Sauther (Eds.), Lemurs: Ecology and adaptation (pp. 97-110). Developments in Primatology: Progress and Prospects. New York: Springer Science+Business Media.

Ganas, J., \& Robbins, M. M. (2005). Ranging behavior of the mountain gorillas (Gorilla beringei beringei) in Bwindi impenetrable National Park, Uganda: A test of the ecological constraints model. Behavioral Ecology and Sociobiology, 58, 277-288.

Ganzhorn, J. U. (1993). Flexibility and constraints of Lepilemur ecology. In P. M. Kappeler \& J. U. Ganzhorn (Eds.), Lemur social systems and their ecological basis (pp. 153-156). New York: Plenum Press.

Ganzhorn, J. U. (2002). Distribution of a folivorous lemur in relation to seasonally varying food resources: Integrating quantitative and qualitative aspects of food characteristics. Oecologia, 131(3), 427-435.

Ganzhorn, J., Lowry, P., Schatz, G., \& Sommer, S. (2001). The biodiversity of Madagascar: One of the world's hottest hotspots on its way out. Oryx, 35(4), 346-348.

Ganzhorn, J. U., Klaus, S., Ortmann, S., \& Schmid, J. (2003). Adaptations to seasonality: Some primate and nonprimate examples. In P. M. Kappeler \& M. E. Pereira (Eds.), Primate life histories and socioecology (pp. 132-144). Chicago: University of Chicago Press.

Ganzhorn, J. U., Pietsch, T., Fietz, J., Gross, S., Schmid, J., \& Steiner, N. (2004). Selection of food and ranging behaviour in a sexually monomorphic folivorous lemur: Lepilemur ruficaudatus. Journal of Zoology, 263, 393-399.

Garber, P. A. (1993). Seasonal patterns of diet and ranging in two species of tamarin monkeys: Stability versus variability. International Journal of Primatology, 14(1), 145-166.

Geiser, F., Goodship, N., \& Pavey, C. R. (2002). Was basking important in the evolution of mammalian endothermy? Naturwissenschaften, 89, 412-414.

Gilbert, C., McCafferty, D., Le Maho, Y., Martrette, J. M., Giroud, S., et al (2010). One for all and all for one: The energetic benefits of huddling in endotherms. Biological Reviews, 85(3), 545-569.

Grubb, P. J. (2003). Interpreting some outstanding features of the flora and vegetation of Madagascar. Perspectives in Plant Ecology, Evolution and Systematics, 61(2), 125-146.

Gursky, S., \& Nekaris, K. A. I. (Eds.) (2007). Primate anti-predator strategies. Developments in primatology: Progress and prospects. New York: Springer Science+Business Media.

Harcourt, C. (1986). Seasonal variation in the diet of south African Galagos. International Journal of Primatology, 7(5), 491-506.

Hemingway, C. A., \& Bynum, N. (2005). The influence of seasonality on primate diet and ranging. In D. K. Brockman \& C. P. van Schaik (Eds.), Seasonality in primates: Studies of living and extinct human and non-human primates (pp. 57-104). Cambridge: Cambridge University Press.

Hendershott, R., Behie, A., \& Rawson, B. (2016). Seasonal variation in the activity and dietary budget of cat Ba langurs (Trachypithecus poliocephalus). International Journal of Primatology, 37, 586-604.

Hiatt, C. (2015) PointsToPaths plugin for quantum GIS. Open Source: https://github.com/chiatt/pointstopaths Hijmans, R. J. (2016). raster: Geographic data analysis and modeling. R package version 2.5-8.

Hilgartner, R. (2006). Living apart together: Pair-living in red-tailed sportive lemurs (Lepilemur ruficaudatus). Ph.D. thesis, Universität Ulm.

Hill, D. A. (1997). Seasonal variation in the feeding behavior and diet of Japanese macaques (Macaca fuscata yakui) in lowland forest of Yakushima. American Journal of Primatology, 43, 305-322.

Hill, R. (2005). Day length seasonality and the thermal environment. In D. K. Brockman \& C. P. van Schaik (Eds.), Seasonality in primates: Studies of living and extinct human and non-human primates (pp. 197214). Cambridge: Cambridge University Press.

Hladik, C. M., \& Charles-Dominique, P. (1974). The behaviour and ecology of the sportive lemur (Lepilemur mustelinus) in relation to its dietary peculiarities. In R. Martin, G. Doyle, \& A. Wlaker (Eds.), Prosimian biology (pp. 23-37). London: Duckworth.

Hladik, C. M., Charles-Dominique, P., \& Petter, J.-J. (1980). Feeding strategies of five nocturnal prosimians in the dry forest of the west coast of Madagascar. In P. Charles-Dominique, H. M. Cooper, A. Hladik, E. Pages, G. F. Pariente, et al (Eds.), Nocturnal Malagasy primates: Ecology, physiology, and behavior (pp. 41-73). New York: Academic Press.

Hoffman, T. S., \& O'Riain, M. J. (2011). The spatial ecology of chacma baboons (Papio ursinus) in a humanmodified environment. International Journal of Primatology, 32, 308-328.

Hrdy, S. B. (1980). The langurs of Abu: Female and male strategies of reproduction. Cambridge: Harvard University Press. 
Irwin, M. T., Raharison, J. L., \& Wright, P. C. (2009). Spatial and temporal variability in predation on rainforest primates: Do forest fragmentation and predation act synergistically? Animal Conservation, 12, 220-230.

Irwin, M. T., Raharison, J.-L., Raubenheimer, D., Chapman, C. A., \& Rothman, J. M. (2014). Nutritional correlates of the "lean season": Effects of seasonality and frugivory on the nutritional ecology of diademed sifakas. American Journal of Physical Anthropology, 153(1), 78-91.

Kappeler, P. M., \& Ganzhorn, J. U. (Eds.) (1993). Lemur social systems and their ecological basis. New York: Springer.

Karanewsky, C. J., \& Wright, P. C. (2015). A preliminary investigation of sleeping site selection and sharing by the brown mouse lemur Microcebus rufus during the dry season. Journal of Mammalogy, 96(6), 1344 1351.

Karpanty, S. M., \& Wright, P. C. (2007). Predation on lemurs in the rainforest of Madagascar by multiple predator species: Observations and experiments. In S. L. Gursky \& K. A. I. Nekaris (Eds.), Primate antipredator strategies (pp. 75-97). Developments in Primatology: Progress and Prospects. New York: Springer Science+Business Media.

Katajisto, J., \& Moilanen, A. (2006). Kernel-based home range method for data with irregular sampling intervals. Ecological Modelling, 194(4), 405-413.

Knox, C. M., \& Wright, P. G. (1989). Thermoregulation and energy metabolism in the lesser bush baby, Galago senegalensis moholi. South African Journal of Zoology, 24(2), 89-94.

Kobbe, S., Nowack, J., \& Dausmann, K. H. (2014). Torpor is not the only option: Seasonal variations of the thermoneutral zone in a small primate. Journal of Comparative Physiology B: Biochemical, Systemic, and Environmental Physiology, 184, 789-797.

Kotze, J., Bennett, N. C., \& Scantlebury, M. (2008). The energetics of huddling in two species of mole-rat (Rodentia: Bathyergidae). Physiology and Behavior, 93, 215-221.

Kurland, J. A., \& Pearson, J. D. (1986). Ecological significance of hypometabolism in nonhuman primates: Allometry, adaptation, and deviant diets. American Journal of Physical Anthropology, 71, 445-457.

Lane, J. E., Boutin, S., Speakman, J. R., \& Humphries, M. M. (2010). Energetic costs of male reproduction in a scramble competition mating system. Journal of Animal Ecology, 79(1), 27-34.

Lieth, H. (1974). Phenology and seasonality modeling. Berlin: Springer-Verlag.

Mitani, J. C., \& Watts, D. P. (2005). Seasonality in hunting by non-human primates. In D. K. Brockman \& C. P. van Schaik (Eds.), Seasonality in primates (pp. 215-242). Cambridge: Cambridge University Press.

Mittermeier, R. A., Langrand, O., Louis, E. E., Richardson, M., Schwitzer, C., et al. (2010). Lemurs of Madagascar (3rd edition). Conservation International.

Morland, H. S. (1993). Seasonal behavioral variation and its relationship to thermoregulation in ruffed lemurs (Varecia variegata variegata). In P. M. Kappeler \& J. U. Ganzhorn (Eds.), Lemur social systems and their ecological basis (pp. 193-203). New York: Springer.

Myers, N., Fonseca, G. A. B., Mittermeier, R. A., \& Kent, J. (2000). Biodiversity hotspots for conservation priorities. Nature, 403, 853-858.

Nash, L. T. (1998). Vertical clingers and sleepers: Seasonal influences on the activities and substrate use of Lepilemur leucopus at Beza Mahafaly special reserve, Madagascar. Folia Primatologica, 69, 204-217.

Nowack, J., Wippich, M., Mzilikazi, N., \& Dausmann, K. H. (2013). Surviving the cold, dry period in Africa: Behavioural adjustments as an alternative to heterothermy in the African lesser bushbaby (Galago moholi). International Journal of Primatology, 34, 49-64.

Ortmann, S., Heldmaier, G., Schmid, J., \& Ganzhorn, J. U. (1997). Spontaneous daily torpor in Malagasy mouse lemurs. Naturwissenschaften, 84, 28-32.

Ostner, J. (2002). Social thermoregulation in redfronted lemurs (Eulemur fulvus rufus). Folia Primatologica, 73(4), 175-180.

Paterson, J. D. (1983). Postural-positional thermoregulatory behaviour and ecological factors in primates. In XIth International Congress of Anthropological and Ethnological Sciences, Québec City (pp. 3-11).

Pebesma, E. J., \& Bivand, R. S. (2005). Classes and methods for spatial data in R. R News, 5(2).

Peres, C. A. (1994). Primate responses to phenological changes in an Amazonian terra firme forest. Biotropica, 26(1), 98-112.

Perret, M. (1998). Energetic advantage of nest-sharing in a solitary primate, the lesser mouse lemur (Microcebus murinus). American Society of Mammalogists, 79(4), 1093-1102.

Pozo-Montuy, G., \& Serio-Silva, J. C. (2007). Movement and resource use by a group of Alouatta pigra in a forest fragment in Balancán, México. Primates, 48, 102-107.

Radespiel, U., Cepok, S., Zietemann, V., \& Zimmermann, E. (1998). Sex-specific usage patterns of sleeping sites in grey mouse lemurs (Microcebus murinus) in northwestern Madagascar. American Journal of Primatology, 46, 77-84. 
Raño, M., Kowalewski, M. M., Cerezo, A. M., \& Garber, P. A. (2016). Determinants of daily path length in black and gold howler monkeys (Alouatta caraya) in northeastern Argentina. American Journal of Primatology, 78, 825-837.

Rasmussen, D. T. (1985). A comparative study of breeding seasonality and litter size in eleven taxa of captive lemurs (Lemur and Varecia). International Journal of Primatology, 6(5), 501-517.

Rasmussen, M. A. (2005). Seasonality in predation risk: Varying activity periods in lemurs and other primates. In D. K. Brockman \& C. P. van Schaik (Eds.), Seasonality in primates (pp. 105-128). Cambridge: Cambridge University Press.

Rasoloharijaona, S., Rakotosamimanana, B., Randrianambinina, B., \& Zimmermann, E. (2003). Pair-specific usage of sleeping sites and their implications for social organization in a nocturnal Malagasy primate, the Milne Edwards' sportive lemur (Lepilemur edwardsi). American Journal of Physical Anthropology, 122, 251-258.

Rasoloharijaona, S., Randrianambinina, B., \& Joly-Radko, M. (2010). Does nonnutritive tree gouging in a rainforest-dwelling lemur convey resource ownership as does loud calling in a dry forest-dwelling lemur? American Journal of Primatology, 72, 1062-1072.

Reichard, U. (1998). Sleeping sites, sleeping places, and presleep behavior of gibbons (Hylobates lar). American Journal of Primatology, 46, 35-62.

Reinhardt, K. D., Wirdateti, \& Nekaris, K. A.-I. (2016). Climate-mediated activity of the Javan slow loris, Nycticebus javanicus. AIMS Environmental Science, 3(2), 249-260.

Ren, B., Li, M., Long, Y., \& Wei, F. (2009). Influence of day length, ambient temperature, and seasonality on daily travel distance in the Yunnan snub-nosed monkey at Jinsichang, Yunnan, China. American Journal of Primatology, 71, 233-241.

Richard, A. F., Dewar, R. E., Schwartz, M., \& Ratsirarson, J. (2002). Life in the slow lane? Demography and life histories of male and female sifaka (Propithecus verreauxi verreauxi). Journal of Zoology, 256, 421436.

Ruperti, F. S. (2007). Population density and habitat preferences of the Sahamalaza sportive lemur (Lepilemur sahamalazensis) at the Ankarafa Research Site, NW Madagascar. Masters thesis, University of Oxford Brookes.

Sato, H. (2012). Diurnal resting in brown lemurs in a dry deciduous forest, northwestern Madagascar: Implications for seasonal thermoregulation. Primates, 53, 255-263.

Sato, H. (2013). Habitat shifting by the common brown lemur (Eulemur fulvus fulvus): A response to food scarcity. Primates, 54, 229-235.

Sato, H., Ichino, S., \& Hanya, G. (2014). Dietary modification by common brown lemurs (Eulemur fulvus) during seasonal drought conditions in western Madagascar. Primates, 55, 219-230.

Savagian, A., \& Fernandez-Duque, E. (2017). Do predators and thermoregulation influence choice of sleeping sites and sleeping behaviour in Azara's owl monkeys (Aotus azarae azarae) in northern Argentina. International Journal of Primatology, 38, 80-99.

Schmid, J. (2000). Daily torpor in the gray mouse lemur (Microcebus murinus) in Madagascar: Energetic consequences and biological significance. Oecologia (Berlin), 123, 175-183.

Schmid, J., \& Ganzhorn, J. U. (1996). Resting metabolic rates of Lepilemur ruficaudatus. American Journal of Primatology, 38, 169-174.

Schmid, J., \& Kappeler, P. M. (2005). Physiological adaptations to seasonality in nocturnal primates. In D. Brockman \& C. P. van Schaik (Eds.), Seasonality in primates: Studies of living and extinct human and non-human primates (pp. 129-156). Cambridge: Cambridge University Press.

Schnoell, A. V., \& Fichtel, C. (2011). Predation on redfronted lemurs (Eulemur rufifrons) by fossas (Cryptoprocta ferox). Lemur News, 16, 30-32.

Schülke, O., \& Ostner, J. (2007). Physiological ecology of cheirogaleid primates: Variation in hibernation and torpor. Acta Ethologica, 10, 13-21.

Schwitzer, N., Randriatahina, G. H., Kaumanns, W., \& Hoffmeister, D. (2007). Habitat utilization of blue-eyed black lemurs, Eulemur flavifrons (gray, 1867), in primary and altered forest fragments. Primate Conservation, 22(1), 79-87.

Seaman, D. E., \& Powell, R. A. (1996). An evaluation of the accuracy of kernel density estimators for home range analysis. Ecology, 77(7), 2075-2085.

Seiler, M., Holderied, M., \& Schwitzer, C. (2013). Effects of habitat degradation on sleeping site choice and use in Sahamalaza sportive lemurs (Lepilemur sahamalazensis). International Journal of Primatology, 34, 260-280.

Seiler, M., Holderied, M., \& Schwitzer, C. (2014). Habitat selection and use in the critically endangered Sahamalaza sportive lemur Lepilemur sahamalazensis in altered habitat. Endangered Species Research, 24(3), 273-286. 
Seiler, M., Holderied, M., \& Schwitzer, C. (2015). Home range size and social organization of the Sahamalaza sportive lemur, Lepilemur sahamalazensis. Primate Conservation, 29, 55-66.

Simmen, B., Bayart, F., Rasamimanana, H., Zahariev, A., Blanc, S., \& Pasquet, P. (2010). Total energy expenditure and body composition in two free-living sympatric lemurs. PLoS One, 5(3), e9860.

Singhal, S., Johnson, M. A., \& Ladner, J. T. (2007). The behavioral ecology of sleep: Natural sleeping site choice in three Anolis lizard species. Behaviour, 144, 1033-1052.

Smith, A. C., Knogge, C., Huck, M., Lottker, P., Buchanan-Smith, H. M., \& Heymann, E. W. (2007). Longterm patterns of sleeping site use in wild saddleback (Saguinus fuscicollis) and mustached tamarins (S. mystax): Effects of foraging, thermoregulation, predation, and resource defense constraints. American Journal of Physical Anthropology, 134(3), 340-353.

Sparrow, W. A., \& Newell, K. M. (1998). Metabolic energy expenditure and the regulation of movement economy. Psychonomic Bulletin \& Review, 5(2), 173-196.

Steury, T. D., McCarthy, J. E., Roth, T. C., Lima, S. L., \& Murray, D. L. (2010). Evaluation of root-n bandwidth selectors for kernel density estimation. Journal of Wildlife Management, 74(3), 539-548.

Stevens, G. C. (1989). The latitudinal gradient in geographical range: How so many species coexist in the tropics. The American Naturalist, 133(2), 240-256.

Swihart, R. K., \& Slade, N. A. (1997). On testing for independence of animal movements. Journal of Agricultural, Biological, and Environmental Statistics, 2, 48-63.

Tang, C., Huang, L., Huang, Z., Krzton, A., Lu, C., \& Zhou, Q. (2016). Forest seasonality shapes diet of limestone-living rhesus macaques at Nonggang, China. Primates, 57, 83-92.

Tattersall, I., \& Sussman, R. W. (1975). Notes on topography, climate, and vegetation of Madagascar. In Lemur biology (pp. 13-21). New York: Springer.

Terrien, J., Perret, M., \& Aujard, F. (2011). Behavioral thermoregulation in mammals: A review. Frontiers in Bioscience, 16, 1428-1444.

Tutin, C. E. G., \& Fernandez, M. (1993). Relationships between minimum temperature and fruit production in some tropical forest trees in Gabon. Journal of Tropical Ecology, 9(2), 241-248.

van Schaik, C. P., \& Brockman, D. K. (2005). Seasonality in primate ecology, reproduction, and life history: An overview. In D. K. Brockman \& C. P. van Schaik (Eds.), Seasonality in primates (pp. 3-20). Cambridge: Cambridge University Press.

van Schaik, C. P., \& Pfannes, K. R. (2005). Tropical climates and phenology: A primate perspective. In D. K. Brockman \& C. P. van Schaik (Eds.), Seasonality in primates: Studies of living and extinct human and non-human primates (pp. 23-54). Cambridge: Cambridge University Press.

van Schaik, C. P., Terborgh, J. W., \& Wright, S. J. (1993). The phenology of tropical forests: Adaptive significance and consequences for primary consumers. Annual Review of Ecology and Systematics, 24(1), 353-377.

Vasey, N. (2005). Activity budgets and activity rhythms in red ruffed lemurs (Varecia rubra) on the Masoala peninsula, Madagascar: Seasonality and reproductive energetics. American Journal of Primatology, 66, 23-44.

Venables, W. N., \& Ripley, B. D. (2002) Modern applied statistics with R, 4th ed. New York: Springer.

Volampeno, M. S. N., Masters, J. C., \& Downs, C. T. (2011). Home range size in the blue-eyed black lemur (Eulemur flavifrons): A comparison between dry and wet seasons. Mammalian Biology, 76(2), 157-164.

Volampeno, M. S. N., Randriatahina, G., \& Downs, C. T. (2013). Structure and composition of Ankarafa Forest, Sahamalaza-Iles Radama National Park, Madagascar: Implications for the frugivorous endemic blue-eyed black lemur (Eulemur flavifrons). South African Journal of Wildlife Research, 43(2), 91-102.

Wallace, R. B. (2006). Seasonal variations in black-faced black spider monkey (Ateles chamek) habitat use and ranging behavior in a southern Amazonian tropical forest. American Journal of Primatology, 68, 313332 .

Warren, R. D., \& Crompton, R. H. (1997). A comparative study of the ranging behaviour, activity rhythms and sociality of Lepilemur edwardsi (Primates, Lepilemuridae) and Avahi occidentalis (Primates, Indriidae) at Ampijoroa, Madagascar. Journal of Zoology, 243, 397-415.

Webb, D. R., \& King, J. R. (1984). Effects of wetting of insulation of bird and mammal coats. Journal of Thermal Biology, 9(3), 189-191.

Wiktander, U., Olsson, O., Nilsson, S. G. (2001) Seasonal variation in home-range size, and habitat area requirement of the lesser spotted woodpecker (Dendrocopos minor) in southern Sweden. Biological Conservation, 100(3):387-395. 
Wilson, E. O. (Ed.). (1988). Biodiversity. (1st edition) Washington, DC: National Academies Press.

Worton, B. J. (1989). Kernel methods for estimating the utilization distribution in home-range studies. Ecology, 70, 164-168.

Wright, P. C. (1989). The nocturnal primate niche in the New World. Journal of Human Evolution, $18,635-658$.

Wright, P. C. (1999). Lemur traits and Madagascar ecology: Coping with an island environment. American Journal of Physical Anthropology, 42, 31-72.

Zhao, Z. J., \& Wang, D. H. (2007). Effects of diet quality on energy budgets and thermogenesis in Brandt's voles. Comparative Biochemistry and Physiology - A Molecular and Integrative Physiology, 148, 168-177. 